\title{
Exploitation Rates and Management Implications for the Fisheries of Bontanga Reservoir in the Northern Region of Ghana
}

\author{
K. Kwarfo-Apegyah ${ }^{1 *}$, P. K. Ofori-Danson ${ }^{2}$ and F. K. E. Nunoo ${ }^{2}$ \\ ${ }^{1}$ CSIR-Water Research Institute, P. O. Box TL695, Tamale, Ghana \\ ${ }^{2}$ Department of Fisheries and Oceanography, University of Ghana, P. O. Box LG 99, Legon-Accra, \\ Ghana. \\ *Corresponding author; E-mail: kkwarfoapegyah@yahoo.co.uk
}

\begin{abstract}
The exploitation rates of eight major component fishery species, Auchenoglanis occidentalis, Brycinus nurse, Clarias gariepinus, Hemichromis fasciatus, Marcusenius senegalensis, Oreochromis niloticus, Sarotherodon galilaeus and Tilapia zillii, of gill net fishery of Bontanga reservoir, were studied from March 2004 to March 2006 based on lengthbased models. The exploitation rates (E) of A. occidentalis and $H$. fasciatus were 0.7 and 0.6 , which exceeded the optimization $\left(\mathrm{E}_{\mathrm{opt}}\right)$ criterion of 0.5 for sustainable exploitation of fisheries, indicating that these species were over exploited. For $B$. nurse and $S$. galilaeus, $\mathrm{E} \approx 0.5$, indicating that these species were at their maximum rates of exploitation. For $C$. gariepinus, $M$. senegalensis, $O$. niloticus and $T$. zillii, $\mathrm{E}<0.5$, indicating that these species were not over exploited. Based on the selection factor of the legal minimum gill net mesh size of $5 \mathrm{~cm}$ of Ghana Fisheries Act 625, the estimated mesh size for catching the eight species ranged from 9.9-19.3 cm, calling for an upward review of the legal minimum mesh size of gill nets from 5 to $10 \mathrm{~cm}$ for sustainable exploitation of reservoir fisheries. The adoption of minimum mesh size of gill nets of $10 \mathrm{~cm}$, restriction of further entry into the fishery, control rights and community based co-management system are some management options suggested to enhance sustainable exploitation and management of the fisheries.
\end{abstract}

\section{Introduction}

Fish from rivers, reservoirs and dugouts play a vital role in the provision of fish protein to the people of northern Ghana. However, for 20 years dwindling catches from these resources have become a common knowledge. Possible reasons for the decline in catches have been attributed to over-exploitation of stocks, environmental degradation and low water levels that have impacted negatively on fish production. (Abban et al., 2002; Amevenku \& Quacoopome, 2006). Obodai \& Waltia (2003) attributed the dwindling catches in Tono reservoir, the largest reservoir in northern Ghana (Irrigation Development Authority, Northern Region, Tamale, Ghana (IDA)) to poor management practices and over-exploitation. Albeit the decline in reservoir fisheries, Bontanga reservoir has high fish species richness (Kwarfo-Apegyah, 2008).

Datua (1989) undertook a 3-month survey of the fisheries of Bontanga reservoir and recorded 10 species as being of commercial importance. Kwarfo-Apegyah (2008) identified 26 fish species belonging to 19 genera in 11 families from commercial gill net fishing during March 2004 to March 2006. The high fish species richness of the reservoir is an indication for potentially high fish production with adoption of appropriate management measures. This is in agreement with the need for countries to manage their fisheries sustainably as emphasised in the 'Code of conduct for responsible fisheries' (FAO, 1997).

The objective of the study is to assess the current exploitation rates of the major component fishery species of the reservoir and suggest management options to enhance management of the reservoir fisheries for sustainable exploitation.

Study area

\section{Materials and methods}

The Bontanga reservoir (Fig. 1) was formed by construction of a dam across Bontanga river, a tributary of the White Volta. The constructional works of the reservoir commenced in 1981 and the reservoir was commissioned in 1986. The reservoir was primarily constructed to support irrigation 
agriculture, watering of livestock and to serve as domestic water source to surrounding communities. The expanse of water created by the reservoir has also provided fisheries resource that provides livelihood opportunities to fishers in the riparian communities and migrant fishers from southern Ghana.

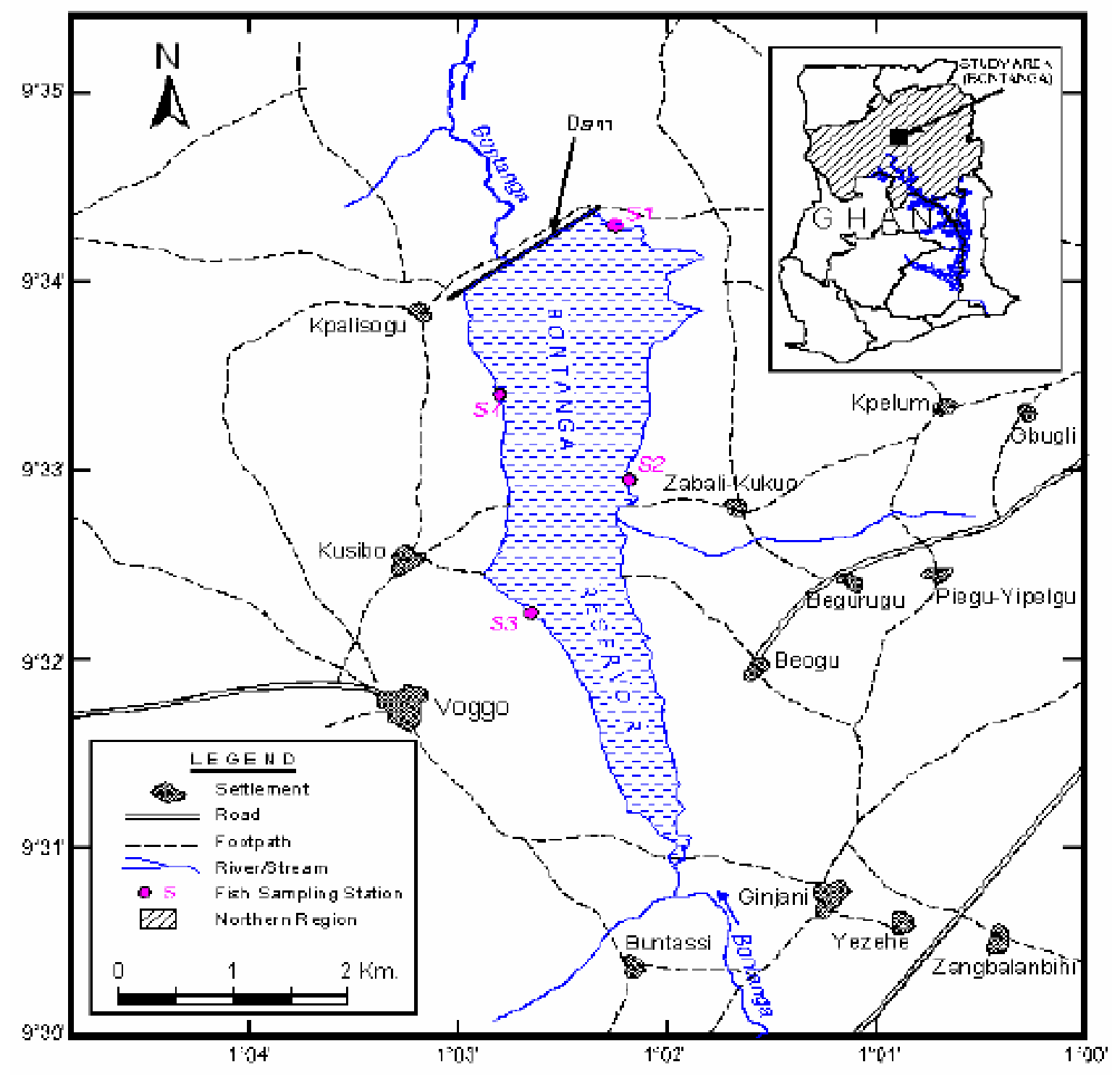

Fig. 1.The location of Bontanga reservoir and fish sampling stations

The vegetation of the catchment area of the reservoir is degraded savanna woodland. The vegetation has been degraded through the combined effect of annual bush fires, farming, exploitation of wood for fuel, and grazing by livestock. The effect of the vegetation degradation is the exposure of the reservoir to direct sunshine and high wind speed, leading to high evapotranspiration rate; coupled with the use of reservoir water for irrigation, wide fluctuations in water level of the reservoir occur during the year.

The mean statistics of rainfall of the location of the reservoir from 1995 to 2006 compiled by the Savanna Agricultural Research Institute (SARI), Nyankpala, in the Northern Region of Ghana, was $906.30 \mathrm{~mm}$ while the mean relative humidity was $63.64 \%$. The mean annual minimum and maximum air temperatures recorded during that period were $24.6{ }^{\circ} \mathrm{C}$ and $33.65{ }^{\circ} \mathrm{C}$, respectively. 
Data source and analysis

Fish samples were collected from gill net catches of fishermen monthly, from March 2004 to February 2006. The mesh size of the gill nets ranged from $4 \mathrm{~cm}$ to $7 \mathrm{~cm}$. The fishermen set their gill nets by 6 p.m. and retrieved them by 8 a.m. the following morning. All fish in a sample were identified using keys provided by Leveque et al. (1992). Each fish was measured for standard length (SL) in centimetres and weighed to $0.1 \mathrm{~g}$ accuracy. Monthly length frequency $(\mathrm{SL} \mathrm{cm})$ was compiled from the length measurements of fish samples. Data was grouped into classes with interval of $1.0 \mathrm{~cm}$ to obtain a length-frequency table, and stored in FiSAT II (Gayanilo et al.,1988) for subsequent analysis.

Determination of growth parameters $\left(\mathrm{L}_{\infty}, \mathrm{K} \& \mathrm{t}_{\mathrm{o}}\right)$. Growth of the target fish species was assumed to follow von Bertalanffy growth function (VBGF), which has been shown to conform to observed growth of most fish species (Sparre \& Venema,1992). The ELEFAN 1 module in FiSAT II was used to estimate the growth parameters $\left(\mathrm{L}_{\infty} \& \mathrm{~K}\right)$ of VBGF for standard length (L) at age (t) (Pauly, 1984; Sparre \& Venema, 1992):

$\mathrm{L}_{\mathrm{t}}=\mathrm{L}_{\infty}\left\{1-\exp \left[-\mathrm{K}\left(\mathrm{t}-\mathrm{t}_{\mathrm{o}}\right)\right]\right\}$ (Sparre \& Venema, 1992),

where $\mathrm{L}_{\infty}$ is the asymptotic length of fish, $\mathrm{K}$, the growth coefficient, and $\mathrm{t}_{\mathrm{o}}$, theoretical age at zero length. $\mathrm{t}_{\mathrm{o}}$ was calculated from the empirical equation:

$$
\log _{10}\left(t_{0}\right)=0.392-0.275 \log _{10} L_{\infty}-1.038 \log _{10} K \text { (Pauly, (1979). }
$$

Determination of total mortality $(Z)$. The total mortality $(Z)$ of the fish species was estimated using FiSAT II (Gayanilo et al.,1994) from linearized length-converted catch curve analysis of the length frequency data (Pauly, 1984; King, 1995). The annual total mortality coefficient (Z) of the fish species was determined from the slope of the descending right arm of the length - converted catch curves.

Determination of natural mortality $(M)$. The natural mortality $(\mathrm{M})$ of the fish species was determined by the empirical formula of Pauly (1980) which relates $M, L_{\infty} K$ and the mean annual environmental temperature as follows:

$\log (\mathrm{M})=-0.0066-0.279 \log \left(\mathrm{L}_{\infty}\right)+0.6543 \log (\mathrm{K})+0.463 \log \left(\mathrm{T}{ }^{\circ} \mathrm{C}\right)$, where $\mathrm{M}=$ natural mortality, $\mathrm{K} \& \mathrm{~L}_{\infty}$ are growth parameters from VBGF, and $\mathrm{T}{ }^{\circ} \mathrm{C}$ is the annual mean surface water temperature.

Determination of exploitation rate (E). The estimate of present values of the instantaneous fishing mortality coefficient,

$\left(\mathrm{F}_{\text {present }}\right.$ ), was obtained by the subtraction of $\mathrm{M}$ from $\mathrm{Z}$. The exploitation rate (E) was then computed from the equation: $\mathrm{E}=\mathrm{F} / \mathrm{Z} \quad$ (King, 1995).

Determination of length at first capture $(L c)$. The mean length at first capture $\left(\mathrm{L}_{c}\right.$ or $\left.\mathrm{L}_{50 \%}\right)$ defined as the mean length at which $50 \%$ of the fish entering the gill nets were caught, was estimated by procedures of Sparre \& Venema (1992) and Pauly (1984), using fish catch data during the study period of two gill nets of mesh sizes $5 \mathrm{~cm}$ and $7 \mathrm{~cm}$.

\section{Results}

.The total annual instantaneous mortality coefficient $(\mathrm{Z})$ was determined for only individuals that were fully exploited (points on the descending arm of the catch curves Fig. 2a-h). Individuals that were either incompletely recruited (points on ascending arm of the curves) or in the older age groups whose lengths were close to $L_{\infty}$ (points on descending arm of the curves) were excluded from the regression analysis. 

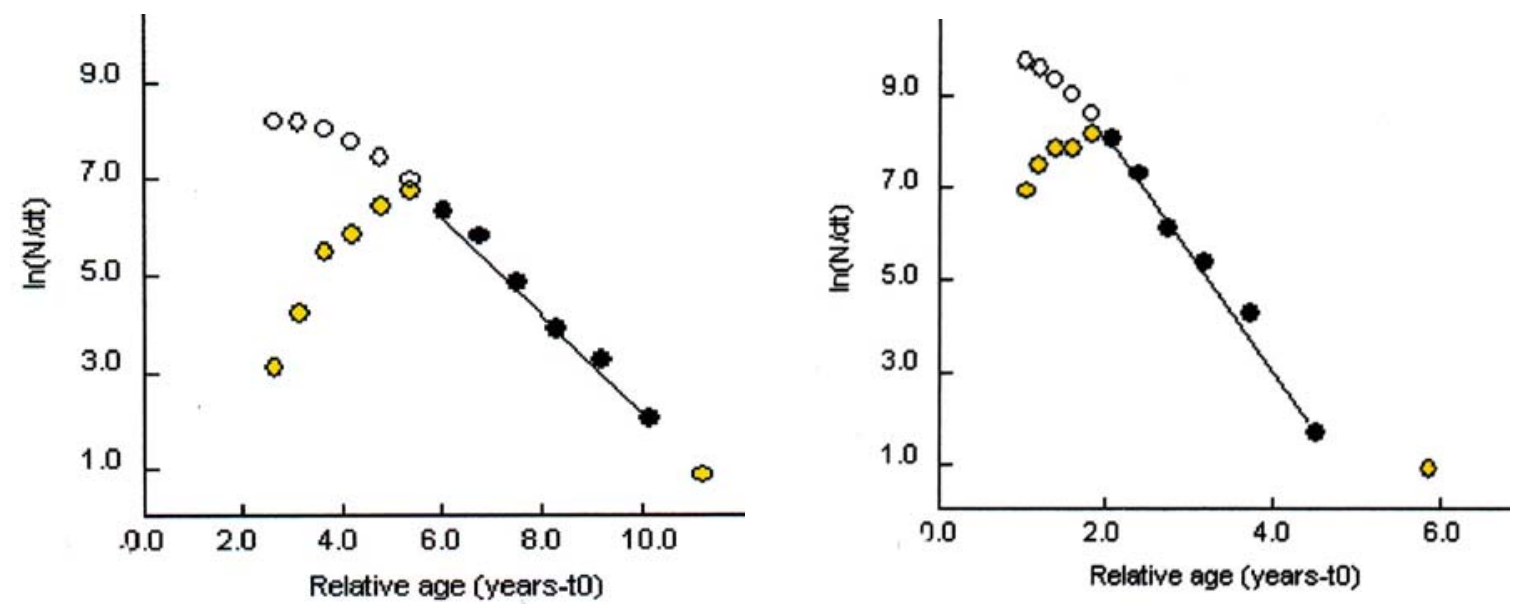

(a) A. occidentalis

$\mathrm{M}=0.34 \mathrm{yr}^{-1} ; \mathrm{F}=0.70 \mathrm{yr}^{-1} ; \mathrm{E}=0.68$.

(b) B.nurse
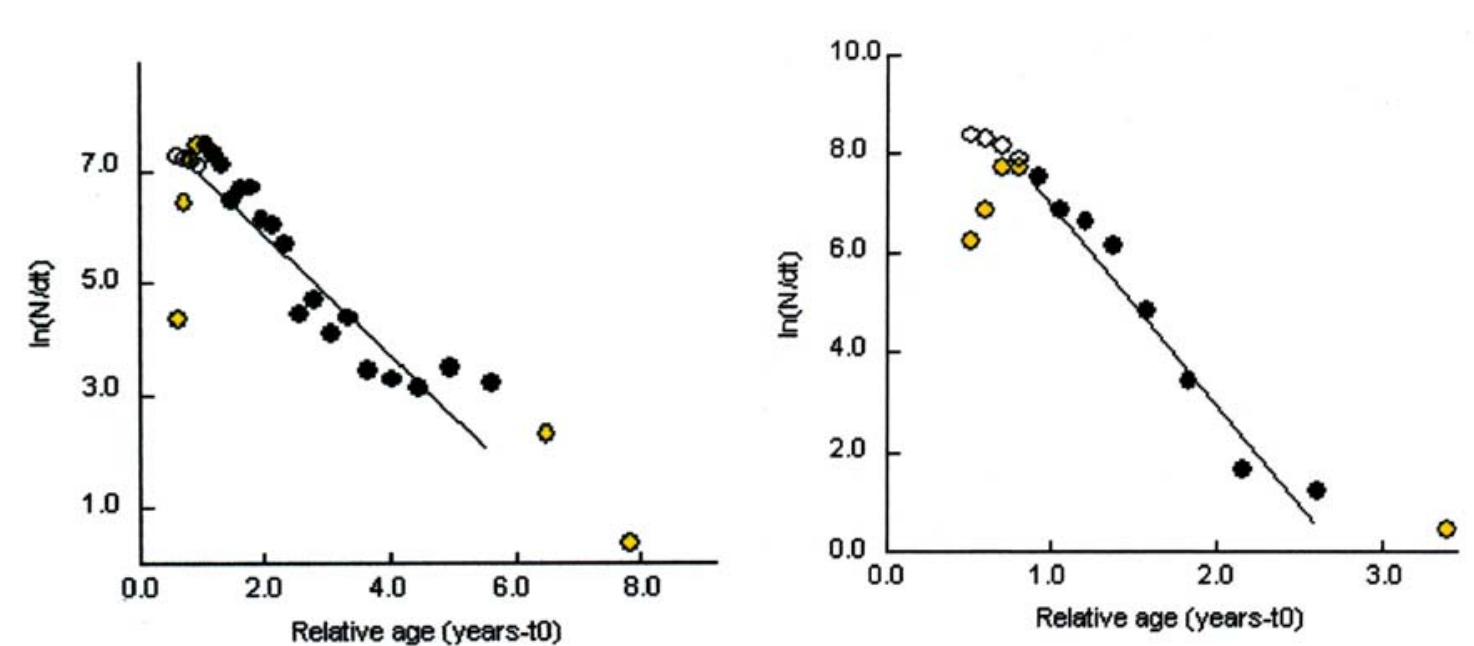

(c) C. gariepinus

(d) H. fasciatus

$\mathrm{M}=0.79 \mathrm{yr}^{-1} ; \mathrm{F}=0.29 \mathrm{yr}^{-1} ; \mathrm{E}=0.27$.

$\mathrm{M}=1.87 \mathrm{yr}^{-1} ; \mathrm{F}=2.27 \mathrm{yr}^{-1}, \mathrm{E}=0.55$.

Legend

Used for analysis

Not used for analysis

Points extrapolated to estimate probability of capture

Fig. 2(a). FiSAT output of Length - converted catch curves for (a) A. occidentalis, (b) B. nurse, (c) C. gariepinus and (d) F. fasciatus of Bontanga reservoir from March 2004 to February 2006 


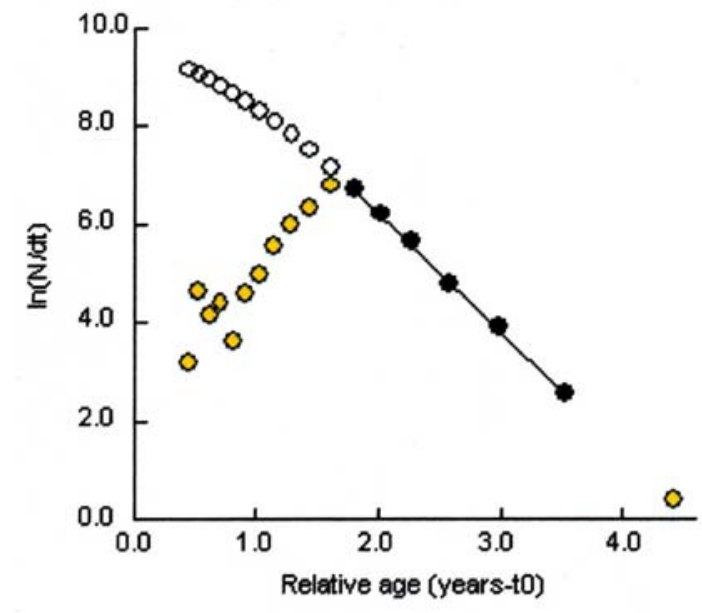

(e) M. senegalensis

$$
\mathrm{M}=1.49 \mathrm{yr}^{-1} ; \mathrm{F}=0.91 \mathrm{yr}^{-1} ; \mathrm{E}=0.38 \text {. }
$$

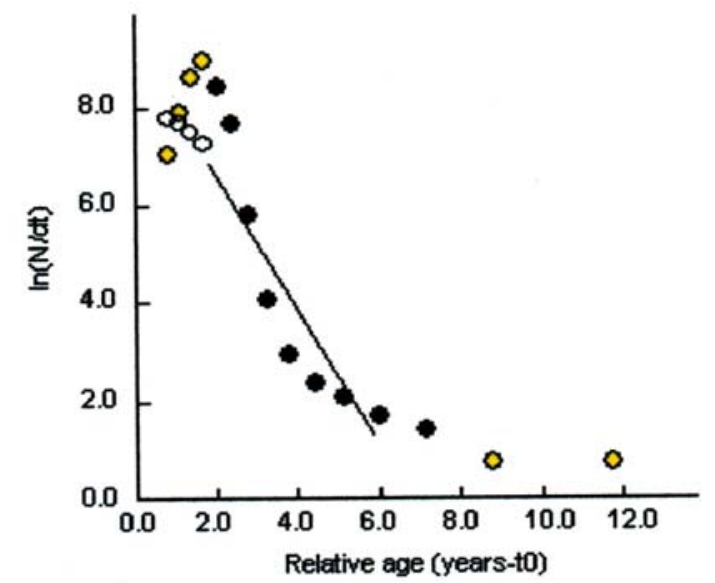

(g) S.galilaeus

$\mathrm{M}=0.70 \mathrm{yr}^{-1} ; \mathrm{F}=0.66 \mathrm{yr}^{-1} ; \mathrm{E}=0.48$.

Legend

Used for analysis

Not used for analysis

Points extrapolated to estimate probability of capture

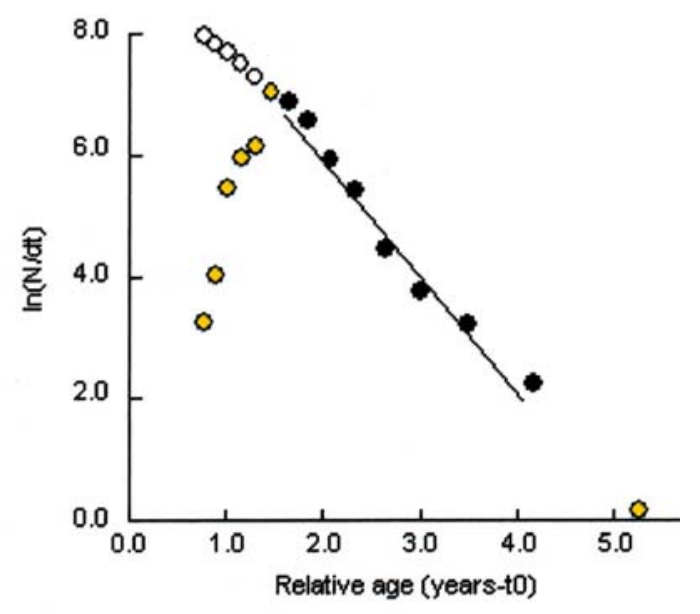

(f) O. niloticus

$\mathrm{M}=1.35 \mathrm{yr}^{-1} ; \mathrm{F}=0.55 \mathrm{yr}^{-1} ; \mathrm{E}=0.29$.

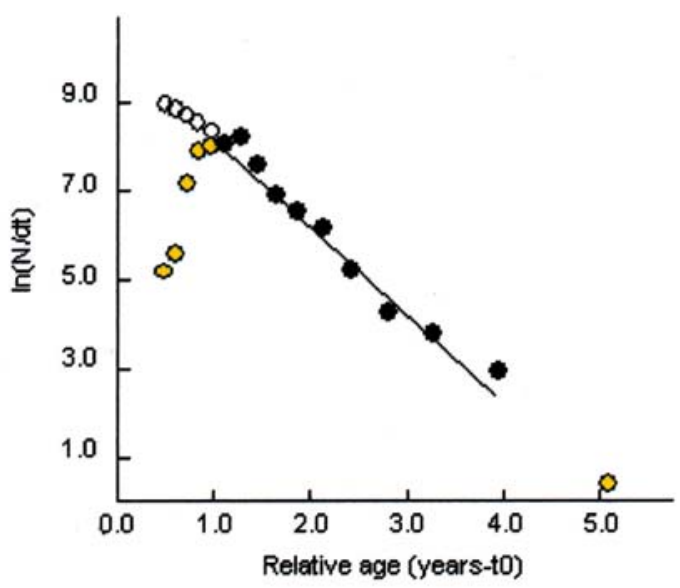

(h) T. zillii

$$
\mathrm{M}=1.41 \mathrm{yr}^{-1} ; \mathrm{F}=0.58 \mathrm{yr}^{-1} ; \mathrm{E}=0.29 \text {. }
$$

Fig. 2b. FiSAT output of Length - converted catch curves for (a) M. senegalensis, (b) O. niloticus, (c) S. galilaeus and (d)

T. zillii of Bontanga reservoir from March 2004 to February 2006

TABLE 1

Summary of population parameters of the eight major fishery components of Bontanga reservoir fron March 2004 to March 2006

$\begin{array}{lllllllll}\text { Parameters } & \begin{array}{l}\text { Auchenoglanis } \\ \text { occidentalis }\end{array} & \begin{array}{l}\text { Brycinus } \\ \text { nurse }\end{array} & \begin{array}{l}\text { Clarias } \\ \text { gariepinus }\end{array} & \begin{array}{l}\text { Hemichromis } \\ \text { fasciatus }\end{array} & \begin{array}{l}\text { Marcusenius } \\ \text { senegalensis }\end{array} & \begin{array}{l}\text { Oreochromis } \\ \text { niloticus }\end{array} & \begin{array}{l}\text { Sarotherodon } \\ \text { galilaeus }\end{array} & \begin{array}{l}\text { Tilapia } \\ \text { zillii }\end{array} \\ \mathrm{L}_{\infty}(\mathrm{cm}) & 54.08 & 20.48 & 61.95 & 20.48 & 24.68 & 23.63 & 36.75 & 21.53 \\ \mathrm{~K}\left(\mathrm{yr}^{-1}\right) & 0.1 & 0.52 & 0.39 & 0.9 & 0.69 & 0.58 & 0.26 & 0.6 \\ \mathrm{t}_{\mathrm{o}} & -0.08 & -0.1 & -0.07 & -0.1 & -0.09 & -0.1 & -0.8 & -0.1 \\ \mathrm{Z}\left(\mathrm{yr}^{-1}\right) & 1.04 & 2.54 & 1.08 & 4.14 & 2.4 & 1.9 & 1.36 & 1.99\end{array}$

West African Journal of Applied Ecology, vol. 14, 2008 


\begin{tabular}{|c|c|c|c|c|c|c|c|c|}
\hline $\mathrm{M}\left(\mathrm{yr}^{-1}\right)$ & 0.34 & 1.3 & 0.79 & 1.87 & 1.49 & 1.35 & 0.7 & 1.41 \\
\hline $\mathrm{E}$ & 0.68 & 0.49 & 0.27 & 0.55 & 0.38 & 0.29 & 0.48 & 0.29 \\
\hline $\mathrm{F}\left(\mathrm{yr}^{-1}\right)$ & 0.71 & 1.24 & 0.29 & 2.27 & 0.91 & 0.55 & 0.66 & 0.58 \\
\hline \multicolumn{9}{|c|}{$\begin{array}{l}\mathrm{L}_{50}(\mathrm{~cm}) \\
\text { (for } 5 \mathrm{~cm} \text { mesh }\end{array}$} \\
\hline gillnet) & 7.35 & 5.47 & 11.69 & 3.96 & 6.48 & 5.54 & 4.94 & 4.67 \\
\hline $\mathrm{L}_{50} / \mathrm{SF}$ & 14.7 & 10.94 & 19.3 & 9.9 & 16.2 & 13.85 & 9.85 & 11.68 \\
\hline
\end{tabular}

The optimum exploitation rate $\left(\mathrm{E}_{\text {opt }}\right)$ of 0.5 suggested for fishing fish stocks was exceeded for $A$. occidentalis (0.68) and $H$. fasciatus (0.55), indicating over-exploitation of these species (Table 1 ).

For B. nurse and S. galilaeus, E values of 0.49 and 0.48 , respectively, approximate 0.5 , suggesting that these species are at the optimum rates of exploitation (Table 1). In the case of $C$. gariepinus, M. senega-lensis, O.niloticus and T. zillii, E $<0.5$, indicating that these species are not over-exploited.

The estimated mesh size, $\left(\mathrm{L}_{50} / \mathrm{SF}\right)$, for catching the species based on $\mathrm{L}_{50}$ and selection factor (SF) of $5 \mathrm{~cm}$ mesh gillnet, ranged from $9.9 \mathrm{~cm}$ for $H$. fasciatus to $19.3 \mathrm{~cm}$ for $C$. gariepinus (Table 1). This was greater than the legal minimum mesh size of $5 \mathrm{~cm}$ stretched diagonal length for gillnets (Ghana Fisheries Act 625, 2002).

\section{Discussion}

Based on the $\mathrm{E}_{\text {opt. }}=0.5$ optimization criterion of Pauly (1984), A. occidentalis and $H$. fasciatus, with E values of 0.7 and 0.6 , respectively, were over-exploited, while $B$. nurse and $S$. galilaeus $(\mathrm{E}=0.5)$ had reached their maximum exploitation rates. There is, therefore, the need to reduce the exploitation rate for sustainable exploitation and conservation. The exploitation rate could be reduced by observing three scenarios: First, by reducing the number of fishers on the reservoir. Second, by maintaining the current number of fishers and introducing withdrawal rights (Garcia, 2006). Third, by increasing the minimum legal mesh size from $5 \mathrm{~cm}$ (Ghana Fisheries Act 625, 2002) to a precautionary minimum size of $10 \mathrm{~cm}$ bar stretched diagonally. The first option must be accompanied by finding alternative employment to fishers who may be denied access to the fishery. Fishers may not be interested in the alternative employment and the Government may not have the resources to implement such a policy.

In the introduction of withdrawal rights, consideration should be given to input rights by restricting the number of gillnet panels to one and the surface area of each panel; rather than output rights (right to take a certain catch, for example, specified proportion of annual Total allowable catch (TAC) or Individual quota or Individual transferable quota). The problems asso-ciated with this option are monitoring, surveillance and control to ensure com-pliance of regulations on input rights.

The estimated minimum mesh size to catch the fish species sustainably was $9.9 \mathrm{~cm}$ for $H$. fasciatus. Taking into conside-ration the precautionary approach to fisheries management (FAO, 1997), the precautionary minimum size of gillnet should be $10 \mathrm{~cm}$ bar stretched diagonally. This suggests the need for a review of the Ghana Fisheries Act 625 that sets the minimum mesh size of gillnets at $5 \mathrm{~cm}$ for reservoir fisheries. Enforcing the minimum mesh size of $10 \mathrm{~cm}$ would enhance recruitment into the fishery more than the use of the current minimum legal mesh size of $5 \mathrm{~cm}$ of Ghana Fisheries Act 625, 2002. Enhanced recruit-ment would contribute to the ichthyobiomass through growth and reproduction. 
It is suggested that the riparian communities be partnered in the control and management of the fisheries of the reservoir through the formation of community based co-management committees. This is because, as noted by Pinkerton (2002), "when communities or organizations of fishers are included as partners in the planning, design and implementation of the regulations, when they participate in protecting habitat, and even more, when they are part of the drafting of the very policies which underlie management decisions, they grant full legitimacy to the regulations, and are the strongest advocates, monitors, enforcers and implementers of management decisions". Therefore, adopting control rights and community based co-management system will ensure the sustainability of the fishery as community vigilance will protect the fishery from unapproved fishing methods, exceedance of withdrawal rights, pollution of the reservoir environment by human sourced pollutants such as pesticide and faeces, and environmental degradation of the catchment area.

\section{Acknowledgement}

The work forms part of the first author's PhD studies under the reservoir fisheries enhancement programme of the Water Research Institute (WRI) of the Council for Scientific and Industrial Research (CSIR). The authors are grateful to the Director for permission to publish this paper. They acknowledge the assistance of Messrs John Rex Sappah and Harrison Komladjei, Principal Draughtsmen, WRI, for drawing the map of the study area, and thank the staff of Tamale Office of WRI for their assistance in the field data collection.

\section{References}

Abban E. K., Kwarfo-Apegyah K. and Amedorme K. (2002). Annual report on fish monitoring in relation to Orchocerciasis Control Programme in Ghana. CSIR-Water Research Institute, Accra, Ghana. 80 pp.

Amevenku F. Y. and Quarcoopome T. (2006). Fish and Fisheries of Bontanga and Libga reservoirs in northern Ghana, West Africa. West Afr. J. appl. Ecol. 10: 9-19.

Datua E. B. (1989). The fish and fisheries of Bontanga Irrigation Dam in Tamale, Northern Ghana. (Dip. Thesis.) Kwame Nkrumah University of Science and Technology, Kumasi, Ghana. 69 pp.

FAO (1997). Fisheries management. FAO Technical Guidelines for Responsible Fisheries, No. 4. FAO, Rome. 82 pp.

Garcia S. M. (2006). The precautionary approach to fisheries. Progress review and main issues: 1995-2006. FAO Fish. Tech. Paper No. 487. FAO, Rome. 261 pp.

Gayanilo Jr. F. C., Soriano M. and Pauly D. (1988). A draft guide to the COMPLEAT ELEFAN. ICLARM Software Project 2. $65 \mathrm{pp}$.

Ghana Fisheries Act 625 (2002). Fisheries Act of the Government of Ghana.

Gayanilo Jr. F. C., Sparre P. and Pauly D. (1994). The FAO-ICLARM stock assessment tools (FISAT) Users guide. FAO computerized information, series, fisheries. Final Draft. FAO, Rome.

King M. (1995). Fisheries biology, assessment and management. Fishing News Books, Hartnolds Ltd, Bodmin, Cornwall, Great Britain. 341 pp.

Kwarfo-Apegyah K. (2008). Ecology and stock assessment of major fish species of Bontanga reservoir for sustainable management. (PhD. Thesis.) Department of Oceanography and Fisheries, University of Ghana, Legon, 216 pp.

Leveque C., Paugy D. and Teugels G. G. (1992). Faune des poisons d'eaux douces et Saumatres de L'Afrique de L'ouest. Tome 1\&2. ORSTOM, Paris, France. MRAC, Tervuren, Belgium.

Obodai E. A. and Waltia S. C. (2003). Preliminary observation on fishing activities in the Tono dam, Upper East Region, Ghana. Ghana Sci. Ass. J. 5(2): 69-76.

Pauly D. (1979). Theory and management of multispecies: a review with emphasis of the South East Asia demersal fisheries. ICLARM stud. Rev. (1). 35 pp.

Pauly D. (1980). On the interrelationships between natural mortality, growth parameters and mean environmental temperature in 175 fish stocks. J. Cons. CIEM 39 (3): 175-192.

Pauly D. (1984). Fish population dynamics in tropical waters: a manual for use with programmable calculators. ICLARM Contribution No. 143, Makati, Metro, Manila, Philippines. 325 pp.

Pinkerton E. (2002). Partnership in management. A fishery managers guidebook .Management measures and their application. (K. L Cochrane, ed.), pp. 159-175. FAO, Fish Pap. No. 42. FAO, Rome. 231 pp.

Sparre P. and Venema S. C. (1992). Introduction to tropical fish stock assessment. Part 1. Manual. FAO Fish. Tech. Pap. 306/1 Rev. FAO, Rome.

West African Journal of Applied Ecology, vol. 14, 2008 


\title{
An Assessment of the Cichlid Fishery of Bontanga Reservoir, Northern Ghana
}

\author{
P. K. Ofori-Danson ${ }^{1 *}$, and K. Kwarfo-Apegyah ${ }^{2}$ \\ ${ }^{1}$ Department of Oceanography and Fisheries, University of Ghana, P. O. Box LG 59, Legon-Accra, \\ Ghana \\ ${ }^{2}$ CSIR-Water Research Institute, P. O. Box AH 38, Achimota, Ghana \\ *Corresponding author; E-mail: ofdan@ug.edu.gh
}

\begin{abstract}
The stock parameters of three cichlids, Oreochromis niloticus, Sarotherodon galilaeus and Tilapia zillii, which dominated the catches of artisanal gill net fishery in Bontanga reservoir were studied. Estimates of the growth and mortality parameters of the stocks enabled application of Beverton and Holt Relative yield-per-recruit (Y'/R) models to estimate the maximum sustainable yield-per-recruit (MSY/R), corresponding fishing effort ( $\mathrm{F}_{\mathrm{MSY} / \mathrm{R}}$ ), and the exploitation rate at which $50 \%$ of the biomass-per recruit $\left(\mathrm{E}_{0.5}\right)$ were exploited. On annual basis, growth of the cichlids was described by the von Bertalanffy growth equation: O. niloticus: $\mathrm{L}_{\mathrm{t}}=23.63\left[1-\exp (0.58(\mathrm{t}+0.10)]\right.$; S. galilaeus: $\mathrm{L}_{\mathrm{t}}=36.73[1-\exp (0.26(t+$ 0.10)] and T. zillii: $\mathrm{L}_{\mathrm{t}}=21.53\left[1-\exp (0.60(\mathrm{t}+0.10)]\right.$. The asymptotic length $\left(\mathrm{L}_{\infty}\right)$ range of $21.5-36.8 \mathrm{~cm}$ and the maturity-length ratio $\left(\mathrm{L}_{\mathrm{m}} / \mathrm{L}_{\infty}\right)$ of $0.19-0.39$, which was less than 0.7 , suggested that the fishes were stunted. The mean length at first capture for $O$. nlioticus was $9.1 \mathrm{SL} \mathrm{cm}$ and for $S$. galilaeus and $T$. zillii were $7 \mathrm{SL} \mathrm{cm}$ and $4.5 \mathrm{SL} \mathrm{cm}$, respectively. The $\mathrm{Y}^{\prime} / \mathrm{R}$ analysis indicated that the present exploitation rate $\left(\mathrm{E}_{\text {present }}\right)$ could be increased 1.04 times for $S$. galilaeus and 1.72 times for $O$. niloticus and $T$. zillii to attain optimum exploitation level of 0.5 . As a result, the present fishing effort $\left(\mathrm{F}_{\text {present }}\right)<\mathrm{F}_{\text {MSY/R }}$, indicating that $\mathrm{F}_{\text {present }}$ could be increased without biologically over-exploiting the species. However, the relative biomass- per recruit (B'/R) curve indicated that at $\mathrm{E}_{\text {present }}$ of $0.48>50 \%$ of the biomass-per recruit for S. galilaeus was exploited, which suggested the threat of growth over-fishing. For O. niloticus, $\mathrm{E}_{\text {present }}<\mathrm{E}_{0.5}$ and T. zillii, $\mathrm{E}_{\text {present }}=\mathrm{E}_{0.5}$. The low natural mortality rate range of $0.7-1.41$ year $^{-1}$ suggested that it is ecologically worthwhile to allow the fish to grow to larger size to contribute to the ichthyobiomass for biologically optimum exploitation. This could be facilitated by adoption of closure measures to conserve the fishery.
\end{abstract}

\section{Introduction}

Reservoirs in northern Ghana are primarily constructed to support irrigation agriculture, watering of livestock and serve as domestic water source to both urban and rural communities. The expanse of water created by the reservoirs also provides fisheries resource that ensures occupational fishing to both local and migrant fishermen from southern Ghana. In spite of the thriving fisheries in a total of about 1530 reservoirs of Ghana (National Dam Safety Unit (NDSU), 2007), very little is known about the state of the fish stocks of the reservoirs.

Bontanga reservoir, with the surface area of 770 ha, is the largest reservoir in the Northern Region of Ghana (Irrigation Development Authority (IDA), Northern Region, Tamale, Ghana). In view of its size, the reservoir has the potential of providing the largest bulk of fresh water fish among the reservoirs in the Region, granting that its fisheries are managed scientifically because of the high fish species diversity (Kwarfo-Apegyah, 2008) of the reservoir. Kwarfo-Apegyah (2008) recorded 26 fish species representing 19 genera in 11 families and potential fish yield of $67.6 \mathrm{~kg} /$ ha/year in Bontanga reservoir.

The Bontanga reservoir fishery is dominated by the cichlid fishes, notably Sarotherodon galilaeus, Oreochromis niloticus and Tilapia zillii (Amevenku \& Quarcoopome, 2006; KwarfoApegyah, 2008). Exploitation of the fisheries provides employment, income and enhances the nutritional status through availability of fish protein to the communities around the reservoir (Kwarfo-Apegyah, 2008). Although these cichlids and other fish species are exploited throughout the year by fishers, there is no information on the state of the fish stocks in respect of their level of exploitation. 
As observed for other fisheries resources, sustainable exploitation of the cichlids is necessary if the fisheries are to make any significant continuous impacts on the socio-economic life of the fishing communities around the reservoir. The purpose of this study was to assess the state of the cichlid fishes that form major component of the fishery of Bontanga reservoir in the Northern Region of Ghana to provide the needed baseline information for conservation and management for sustainable exploitation of the cichlid fisheries of the reservoir.

\section{Study area}

\section{Materials and methods}

The Bontanga reservoir is situated in the Tolon/Kumbungu District of the Northern Region of Ghana, where the vegetation is degraded Guinea savanna woodland. The reservoir is located between latitude $9^{\circ} 30^{\prime}$ and $9^{\circ} 35^{\prime} \mathrm{N}$ and longitudes $1^{\circ} 01^{\prime}$ and $1^{\circ} 03^{\prime} \mathrm{W}$ (Fig.1).

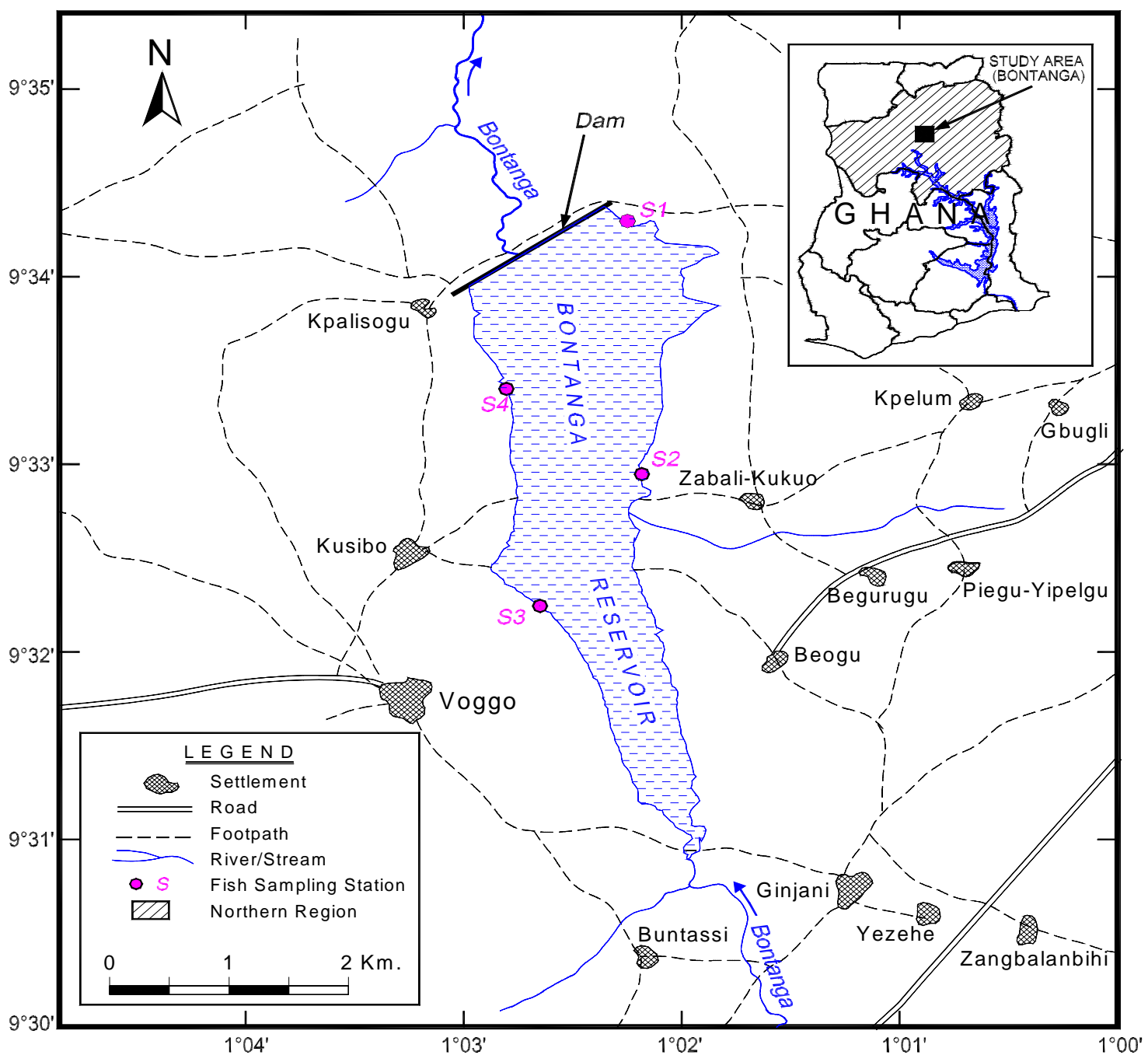

Fig. 1. Location of Bontanga reservoir and fish sampling stations

The Northern Region of Ghana experiences a single rainy season from June to October with annual mean of $1000 \mathrm{~mm}$, solar radiation $>5.0 \mathrm{~K} \mathrm{Wh} / \mathrm{m}^{2} /$ day and potential evapo-transpiration of $1652 \mathrm{~mm}$ per annum, giving an excess evapo-transpiration over rainfall by about $87 \%$ and annual aridity index of 0.54 (Environmental Protection Agency (EPA), 2004). Thus, the reservoir lies in a desert prone area. The physical characteristics of the reservoir are summarized in Table 1. 
TABLE 1

Physical characteristics of Bontanga reservoir

Catchment area

Maximum storage capacity

Maximum depth

Mean depth

Useful storage capacity (Live storage)

Minimum storage capacity (Dead storage)

Flooded area (At full supply land)

Length of reservoir

\author{
$165 \mathrm{~km}^{2}$ \\ 25 million $\mathrm{m}^{3}$ \\ $9 \mathrm{~m}$ \\ $4.9 \mathrm{~m} *$ \\ 20 million $\mathrm{m}^{3}$ \\ 5 million $\mathrm{m}^{3}$ \\ 770 ha \\ $8 \mathrm{~km} .(5 \mathrm{mls})$.
}

* Kwarfo-Apegyah (2008).

Source: Irrigation Development Authority, Northern Region,Tamale, Ghana

\section{Data source}

Sampling and data collection were undertaken monthly from March 2004 to March 2006. The major cichlids landed by artisanal fishermen were sorted into species using keys provided by Paugy et al. (2003ab) and Dankwah et al. (1999). Each species was weighed and counted, and each fish was individually measured for standard length (SL), total length (TL) in centimeters and weight in grams. The fishermen set their gill nets by $18.00 \mathrm{~h}$ and retrieve the catch by $07.00 \mathrm{~h}$ the next morning. Therefore, unit effort of fishing was defined as one gill net set for about $12 \mathrm{~h}$ over night. From the measurements made the following characteristics of the three major cichlids, O. niloticus, S. galilaeus and T. zillii, were estimated.

Length composition of the catch. Monthly length frequency (total length (TL) $\mathrm{cm}$ ) data were compiled from sampled fish length measurements and the distribution determined at $1.0 \mathrm{~cm}$ length intervals.

Stock assessment. The three species, S. galilaeus, O. niloticus and T. zillii, were subjected to single-species length based stock assessment, based on their length frequency distribution. The growth of each species was assumed to follow the von Bertalanffy growth function (Sparre \& Venema, 1992), which has been shown to conform to the observed growth of most fish species, which is given by the equation:

$\mathrm{L}_{\mathrm{t}}=\mathrm{L}_{\infty}\left[1-\exp -\mathrm{K}\left(\mathrm{t}-\mathrm{t}_{\mathrm{o}}\right)\right]$ (Sparre \& Venema, 1992), where $\mathrm{L}_{\mathrm{t}}=$ length at age $\mathrm{t}, \mathrm{L}_{\infty}=$ asymptotic length, $\mathrm{K}=$ growth coefficient and $\mathrm{t}_{\mathrm{o}}=$ theoretical age at zero length ( Pauly,1984; Sparre \& Venema, 1992). The estimate of $\mathrm{L}_{\infty}$ and $\mathrm{K}$ were obtained using ELEFAN 1 routine in the FiSAT software (Gayanilo et al., 1994), while $\mathrm{t}_{\mathrm{o}}$ was computed using the equation:

$$
\log _{10}\left(-t_{0}\right)=-0.392-0.275 \log _{10} L_{\infty}-1.038 \log _{10} K \text { (Pauly, 1979). }
$$

The total instantaneous mortality coefficient (Z) was estimated using FiSAT Gayanilo et al. (1994) by linearized length-converted catch curve analysis (Sparre \& Venema,1992; King, 1995). The natural instantaneous mortality coefficient (M) was computed from the empirical equation of Pauly (1980), which relates $\mathrm{M}, \mathrm{L}_{\infty} \mathrm{K}$ and the mean environmental temperature $\left(\mathrm{T}^{\circ} \mathrm{C}\right)$ :

$$
\log _{10} \mathrm{M}=-0.0066-0.279 \log _{10} \mathrm{~L}_{\infty}+0.6543 \log _{10} \mathrm{~K}+0.4634 \log _{10} \mathrm{~T}{ }^{\circ} \mathrm{C} \text { (Pauly, 1980). }
$$

The fishing mortality rate, $\mathrm{F}$, was estimated from the relationship, $\mathrm{F}=\mathrm{Z}-\mathrm{M}$ (Ricker, 1975), while the exploitation rate (E) of the stocks was also calculated from the equation: $F=F / Z$ (Ricker, 1975). The longevity or natural life span $\left(\mathrm{t}_{\max }\right)$ of the stocks was estimated from the equation:

$\mathrm{t}_{\max } \approx 3 / \mathrm{K}$ (Pauly, 1984), where $\mathrm{K}=$ von Bertalanffy growth coefficient. 
The estimated growth and mortality parameters were used for applying Beverton \& Holt (1957) in (Sparre \& Venema, 1992) relative yield-per recruit (Y'/R) analysis to estimate the maximum sustainable yield-per recruit (MSY/R) and relative biomass-per recruit (B'/R), (Sparre \& Venema, 1992).

The mean length at first capture $\left(\mathrm{L}_{\mathrm{c}}\right)$, defined as the length at which $50 \%$ of the fish entering the gill nets were caught, was estimated by computing the selection factor (SF) of the species using catch data of two gillnets of mesh sizes 5 and $7 \mathrm{~cm}$ bar stretched, as described by Sparre \& Venema (1992) and Pauly (1984). $\mathrm{L}_{\mathrm{c}}$ was computed from the relationship, $\mathrm{L}_{\mathrm{c}}=\mathrm{S} . \mathrm{F} \times$ Mesh size (Sparre \& Venema, 1992; Pauly, 1984). The ratio $\mathrm{L}_{c} / \mathrm{SF}$ that represents an estimate of appropriate mesh size for catching each species (Gulland, 1969) in Ofori-Danson (2005) was calculated.

The mean length at sexual maturity $\left(\mathrm{L}_{\mathrm{m}}\right)$, defined as the length at which $50 \%$ of all individuals were matured, was estimated for females only for each species, since the gonad maturation stages of females were more clearly discernible than males. The gonad maturity stages of females of stage II and above was determined following procedures of Bagenal \& Braum (1968) in Ofori-Danson (1999). $\mathrm{L}_{\mathrm{m}}$ was estimated from the equation: $\mathrm{Ln}(1-\mathrm{P}) / \mathrm{P}=\mathrm{rL}+\mathrm{rL}_{\mathrm{m}}$, (King, 1995) where $\mathrm{P}=$ proportion of matured females, $\mathrm{r}=$ constant and $\mathrm{L}=$ class midpoint.

\section{Relative abundance of the cichlids}

\section{Results}

The three cichlids, O. niloticus, S. galilaeus and T. zillii, constituted $53 \%$ by weight of the fish landed during the sampling events from March 2004 to March 2006. S. galilaeus and O. niloticus constituted $26 \%$ and $20 \%$ by weight of the total catch while T. zillii represented $7 \%$ (Fig. 2). The three species were encountered on every sampling date throughout the study period.

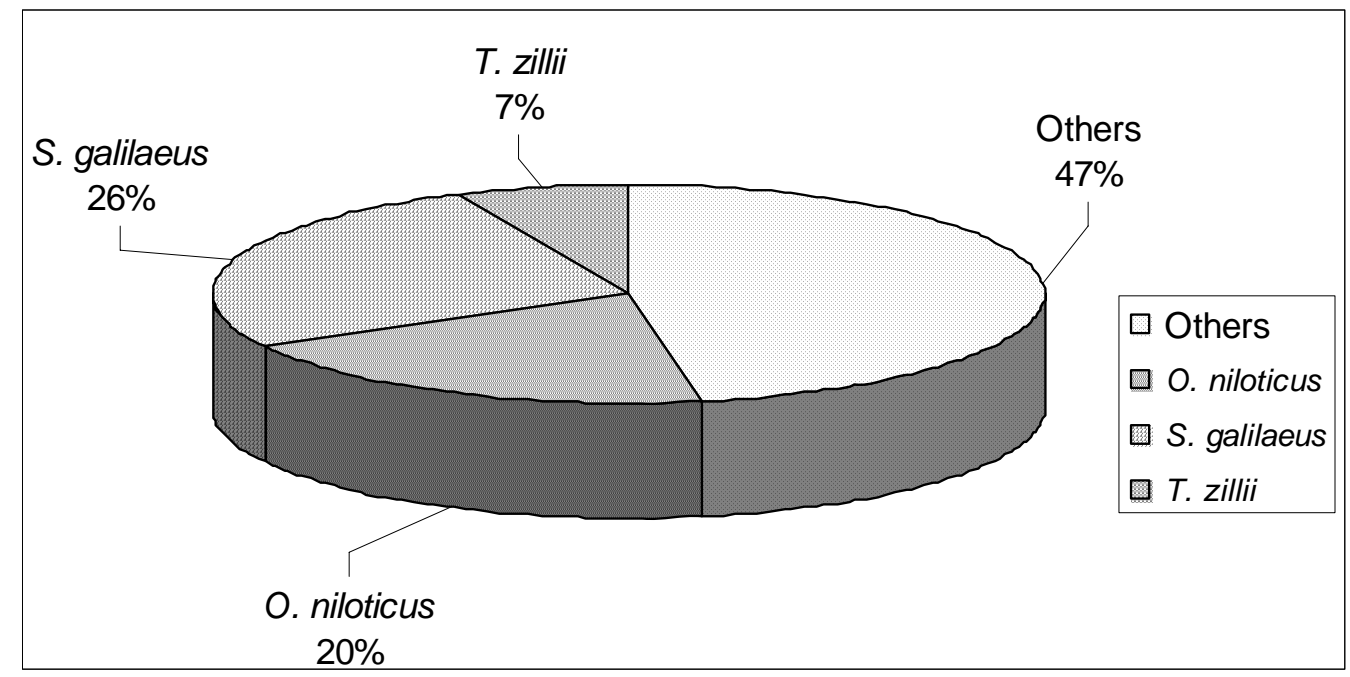

Fig. 2. Relative proportions of major cichlids landed by weight in fish landed by artisanal fishermen in Bontanga reservoir from March 2004 to March 2006

\section{Growth and mortality parameters}

The monthly length-frequency distribu-tions fitted with growth curves by ELEFAN 1 programme of FiSAT II (Gayanilo et al., 1994), are presented in (Fig. 3). On annual basis, the growth of the three species was described by the following von Bertalanffy growth equations:

Oreochromis niloticus:

$\mathrm{L}_{\mathrm{t}}=23.63[1-\exp (-0.58(\mathrm{t}+0.10)]$

Sarotherodon galilaeus:

$\mathrm{L}_{\mathrm{t}}=36.73[1-\exp (-0.26(\mathrm{t}+0.08)]$

Tilapia zillii: 
$L_{t}=21.53[1-\exp (-0.60(t+0.10)]$

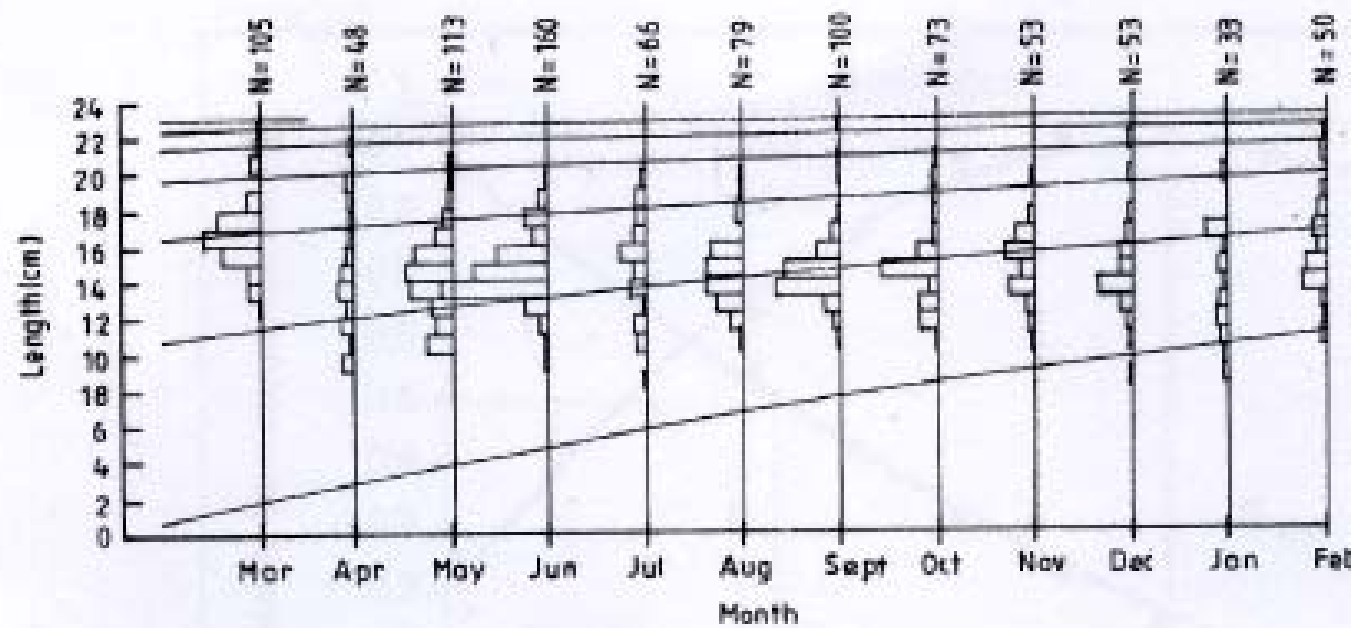

a) O.niloticus $\mathrm{L}_{w}=23.63, \mathrm{~K}=0.58 \mathrm{yr}^{-1}, \mathrm{t}_{\mathrm{o}}=-0.10 \mathrm{yr}$

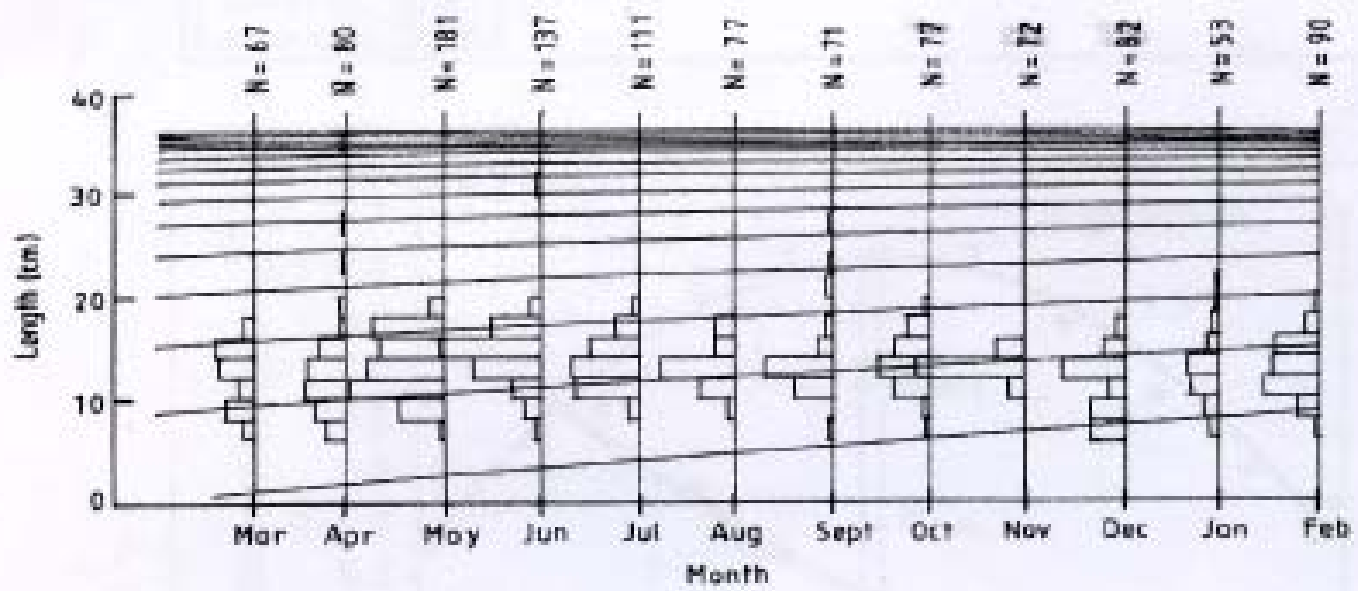

(b) S. galilaeus: $\mathrm{L}_{w}=36.75, \mathrm{~K}=0.26 \mathrm{yr}^{-1}, \mathrm{t}_{\mathrm{o}}=-0.08 \mathrm{yr}$

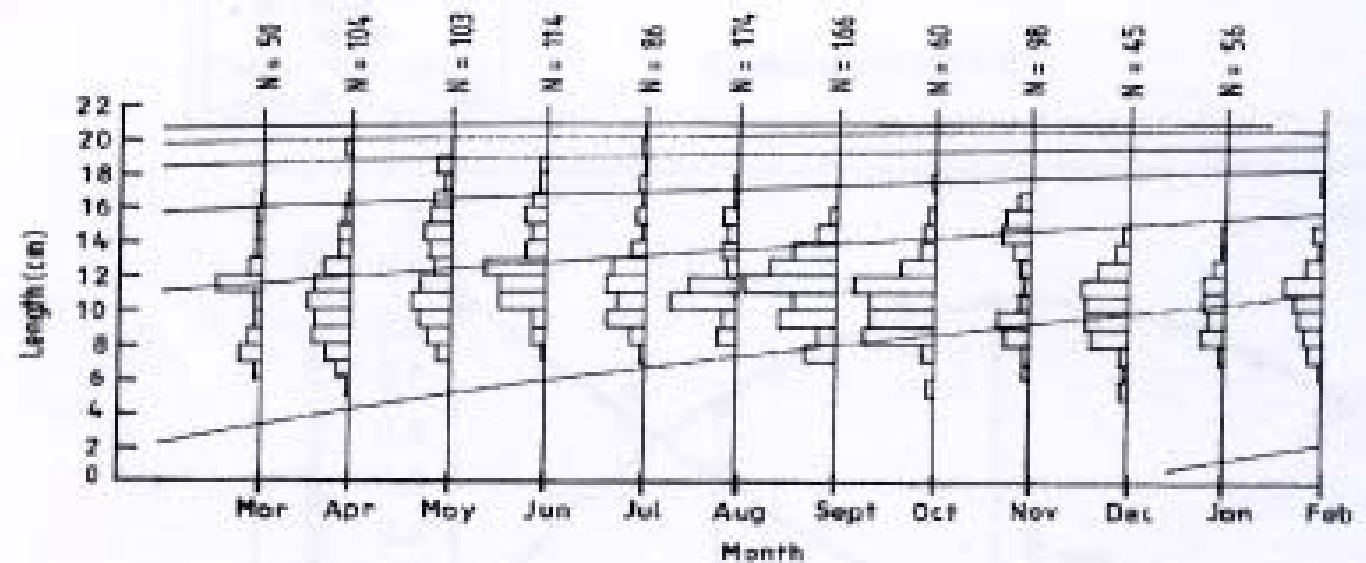

(c) T. zillii: $\mathrm{L}_{w}=21.53 \mathrm{~cm}, \mathrm{~K}=0.60 \mathrm{yr}^{-1}, \mathrm{t}_{\mathrm{o}}=-0.10 \mathrm{yr}$

Legend

$\square$ Monthly total length histogram. / Superimposed growth curve.

Fig. 3. Length frequency distribution with superimposed growth curves for (a) O. niloticus, (b) S. galilaeus and (c) C. gariepinus of Bontanga reservoir from March 2004 to February 2006 
Relative yield-per recruit ( $\left.Y^{\prime} / R\right)$ and relative biomass-per recruit $\left(B^{\prime} / R\right)$

The relative yield-per recruit against exploitation rate (E) plots (Fig. $4 a-c)$ indicated that the present exploitation rates $\left(\mathrm{E}_{\text {present }}\right)<$ the maximum exploitation rate $\left(\mathrm{E}_{\max }\right)$ that could be applied for sustainable exploitation of fisheries, suggesting that $\mathrm{E}_{\text {present }}$ could be increased for all the three species without over-exploiting them. For O. niloticus, the relative Biomass-per recruit against exploitation rate plots associated with the relative yield-per recruit against exploitation rate plots showed that $\mathrm{E}_{\text {present }}<\mathrm{E}_{0.5}$ (the exploitation rate at which $50 \%$ of biomass of the recruit is fished) (Fig. 4a), suggesting that the current exploitation rate did not impact adversely on the recruitment into the fishery as less than $50 \%$ of biomass-per recruit was exploited. However, in the case of $S$. galilaeus, $\mathrm{E}_{\text {present }}>\mathrm{E}_{0.5}$ (Fig. 4b), indicating that, at the current rate of exploitation, there was the threat of growth over fishing as $>50 \%$ of biomass-per recruit was fished. For T. zillii, $\mathrm{E}_{\text {present }}=\mathrm{E}_{0.5}$ (Fig. 4c), indicating that $50 \%$ of the biomass-per recruit was exploited, suggesting that further increase in $\mathrm{E}_{\text {present }}$ would pose a threat of growth over fishing.
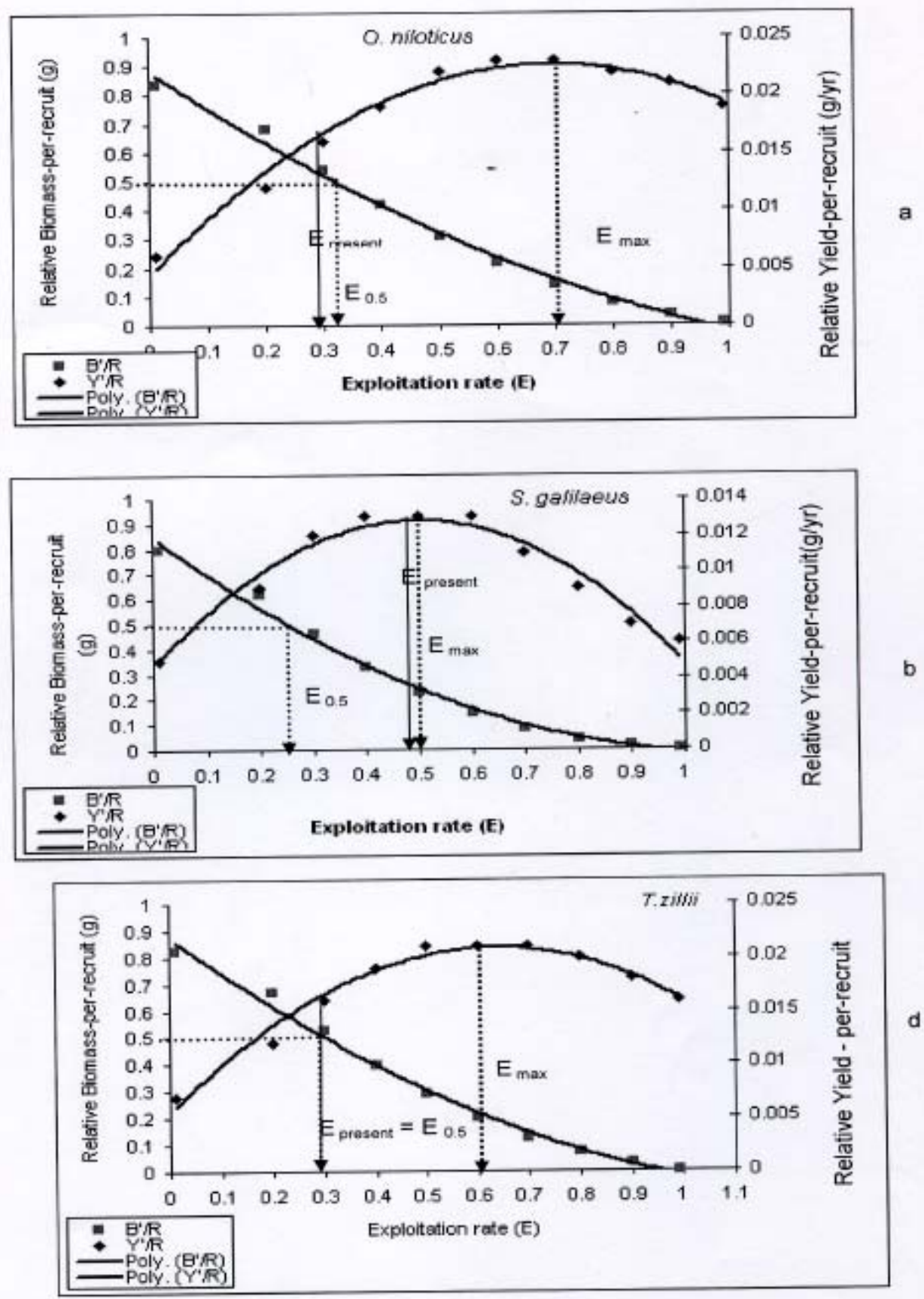

West African Journal of Applied Ecology, vol. 14, 2008 
Figs. 4a-c. Relative yield-per recruit (Y'/R) and Biomass-per recruit (B'/R) plots for a) O. niloticus, b) S. galilaeus and c)

T. zillii at varrying exploitation rates in Bontanga reservoir from March 2004 to February 2006

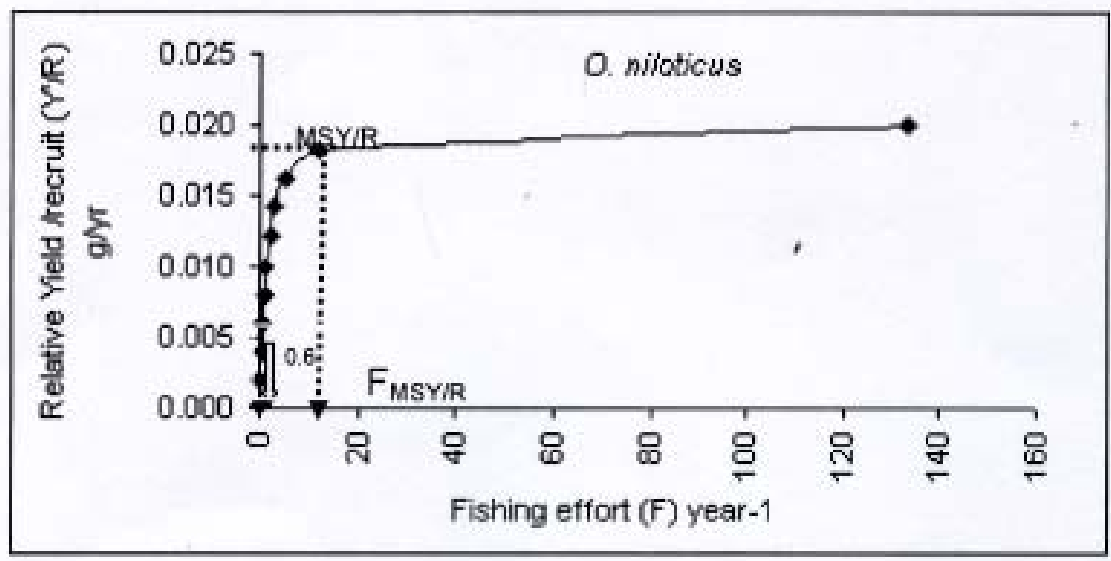

a

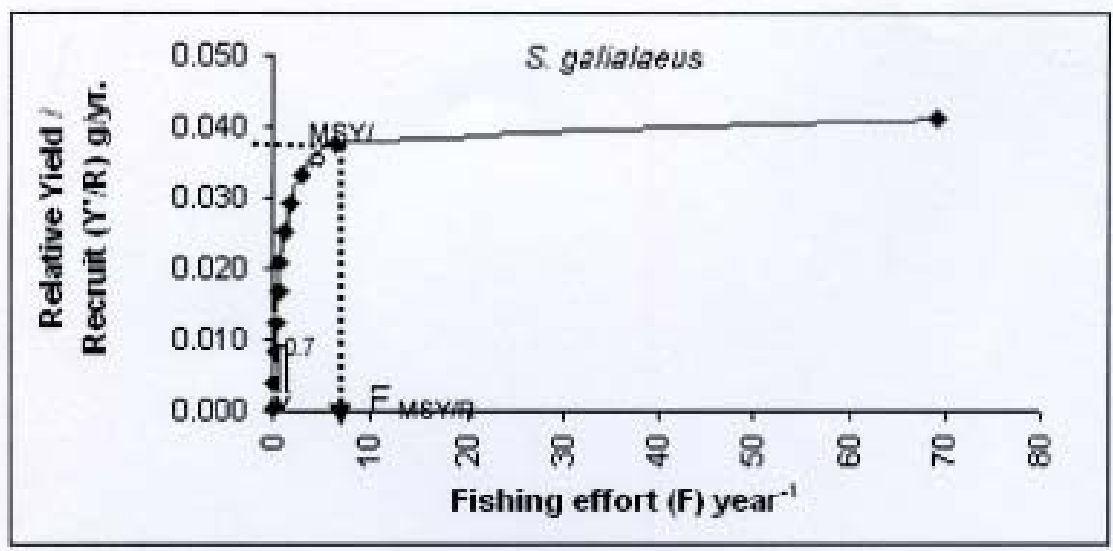

b

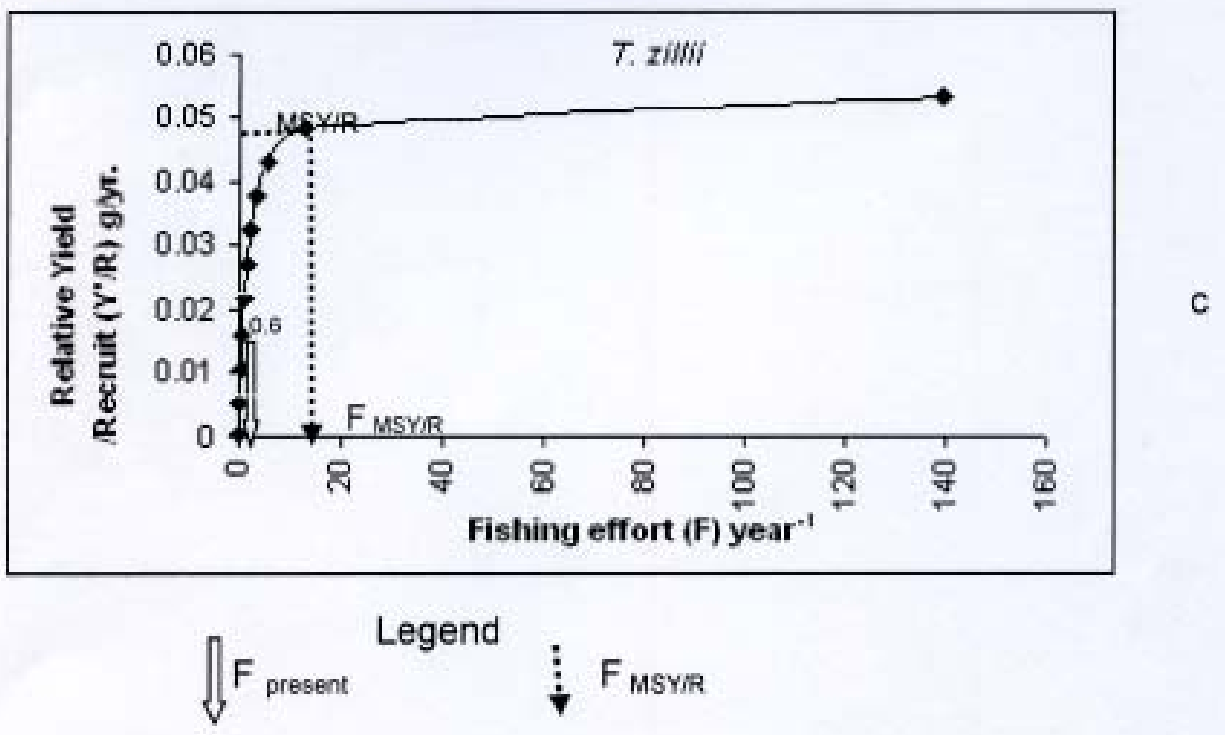

Fig. 5a-c. Relative yield-per recruit (Y’/R) curves for (a) O. niloticus, (b) S. galilaeus and (c) T. zillii

The exploitation rate (E) of O. niloticus and T. zillii of 0.29 (Table 2) suggested that these species were under exploited while the value of $0.48(\approx 0.5)$ indicated that $S$. galilaeus had reached its maximum rate of exploitation according to the optimization $\left(\mathrm{E}_{\mathrm{opt}}\right)$ criterion of $\mathrm{E}=0.5$ of Pauly (1984) for sustainable exploitation of fisheries. 
TABLE 2

Summary of biological parameters of major Cichlids of Bontanga reservoir from March 2004 to February 2006

$\begin{array}{lccc}\text { Parameter } & \begin{array}{l}\text { Oreochromis } \\ \text { niloticus }\end{array} & \begin{array}{l}\text { Sarotherodon } \\ \text { galilaeus }\end{array} & \begin{array}{c}\text { Tilapia } \\ \text { zillii }\end{array} \\ \mathrm{L}_{\infty}(\mathrm{cm}) & 23.63 & 36.75 & 21.53 \\ \mathrm{~K}\left(\text { year }^{-1}\right) & 0.58 & 0.26 & 0.6 \\ \mathrm{t}_{\mathrm{o}}\left(\mathrm{yr}^{-1}\right) & -0.1 & -0.08 & -0.1 \\ \mathrm{t}_{\max }(\mathrm{yr}) & 5.2 & 10.0 & 5.0 \\ \varnothing & 2.55 & 2.55 & 2.44 \\ \mathrm{~L}_{\mathrm{m}}(\mathrm{cm}) & 9.1 & 7 & 4.5 \\ \mathrm{~L}_{\mathrm{m}} / \mathrm{L}_{\infty} & 0.38 & 0.19 & 0.21 \\ \mathrm{~L}_{50}(\mathrm{~cm}) & 5.54 & 4.94 & 4.67 \\ \mathrm{~L}_{50} / \mathrm{SF} & 13.85 & 9.88 & 11.6 \\ \mathrm{SF} & 0.4 & 0.5 & 0.4 \\ \mathrm{Z}\left(\text { year }^{-1}\right) & 1.9 & 1.36 & 1.99 \\ \mathrm{M}\left(\text { year }^{-1}\right) & 1.35 & 0.7 & 1.41 \\ \mathrm{~F}\left(\text { year }^{-1}\right) & 0.55 & 0.66 & 0.58 \\ \mathrm{E}=\mathrm{F} / \mathrm{Z} & 0.29 & 0.48 & 0.29\end{array}$

The relative yield-per recruit against fishing effort plots (Fig. 5a-c), indicated that the present fishing effort $\left(\mathrm{F}_{\text {present }}\right)<\mathrm{F}_{\mathrm{MSY} / \mathrm{R}}$ (the fishing effort required to obtain the maximum sustainable yield-per recruit for all the three species. This suggested that $\mathrm{F}_{\text {present }}$ could be increased to obtain higher catches.

The estimated mesh size of gill net $\left(\mathrm{L}_{50} / \mathrm{SF}\right)$ for catching the species ranged from $9.88-13.85 \mathrm{~cm}$, bar stretched diagonally (Table 2), suggesting that the legal minimum mesh size of $5 \mathrm{~cm}$, prescribed by the Ghana Fisheries Act 625 (2002), was too small for healthy exploitation of the species. The longevity $\left(\mathrm{t}_{\max }\right)$ of 5 and 5.2 years (Table 2) of O. niloticus and T. zillii indicated that these species were relatively short lived while $S$. galilaeus, with $t_{\max }$ value of 10.0 years had relatively longer life span.

\section{Discussion}

O. niloticus, S. galilaeus and T. zillii were fully recruited to the fishery at sizes of 5.54 SL cm, 4.9. SL cm, and 4.7 SL cm, respectively. Therefore, a large proportion of the species sampled were in the small size category range of $2-12 \mathrm{~cm}$ of fresh water fishes of Africa (Pauly, 1995). The asymptotic lengths of 23.6 SL cm, 36.8 SL cm and 21.53 SL cm of O. niloticus, S. galilaeus and T. zilli, respectively, were relatively smaller than that reported in other reservoirs. For example, OforiDanson (1999) reported asymptotic length of $33.5 \mathrm{SL} \mathrm{cm}$ for O. niloticus in Stratum VII of Volta Lake, while Paugy et al. (2003a) recorded 39.5 SL cm maximum lengths for the species in major rivers of West Africa. Paugy et al. (2003a) also recorded maximum length of $40 \mathrm{SL} \mathrm{cm}$ for T. zillii in major rivers of West Africa.

The smaller values of the asymptotic length of the major cichlids in this study suggest possible stunting of the species in Bontanga reservoir. Iles (1970) reported that tilapias (Cichlidae) with normal growth usually attain asymptotic length of $\approx 35 \mathrm{~cm}$ and an average maturity - length ratio $\left(\mathrm{L}_{\mathrm{m}} / \mathrm{L}_{\infty}\right)$ of 0.70 . In this study the $\mathrm{L}_{\mathrm{m}} / \mathrm{L}_{\infty}$ ratio of the major cichlids ranged from 0.19-0.39, which fell below 0.70 for normal growing tilapias (1les, 1973), indicating further the possible stunting of tilapias in Bontanga reservoir. Stunting of tilapia populations have been attributed to high natural mortality rates resulting from intense predation by birds and reptiles in some water bodies (Iles, 1973; Amarasinghe et al., 1989). 
The mortality of the cichlids in Bontanga reservoir was largely attributed to fishing activities. The low natural mortality rates ranging from $0.7-1.4$ of the major cichlids in this study was attributed to the absence of strict piscivorous fish species such as Lates niloticus in the reservoir; only facultative piscivores, Clarias anguillaris, C. gariepinus, Hemichromis fasciatus and Malapterurus electricus, have been identified in the reservoir (Kwarfo-Apegyah, 2008).

A comparison of the growth parameters $\left(\mathrm{L}_{\infty}=23.6 \mathrm{SL} \mathrm{cm} ; \mathrm{K}=0.58 \mathrm{yr}^{-1}\right)$ of $O$. niloticus of Bontanga reservoir and that from Tapoa reservoir of Burkina Faso $\left(\mathrm{L}_{\infty}=36 \mathrm{SL} \mathrm{cm} ; \mathrm{K}=0.39 \mathrm{yr}^{-1}\right)$ (Baijot et al.,1997) indicates that $O$. niloticus grows at a faster rate (about $1 \frac{1 / 2}{2}$ times) in Bontanga reservoir than Tapoa reservoir but obtains an asymptotic length that is about $1 \frac{1}{2}$ times less than that in Tapoa reservoir. Because the O. niloticus in Bontanga reservoir have short life span of about 5 years, they would be expected to reach the asymptotic length at a faster rate. Iles (1973) noted that stunted tilapia populations display characteristically high relative growth rates and attains a smaller $\mathrm{L}_{\infty}$ than normal populations.

The growth rates of the three cichlids have implications in their suitability for culture. Although S. galilaeus grows to a larger asymptotic size than $O$. niloticus and T. zillii, the faster growth rate of $O$. niloticus and T. zillii of 0.58 and 0.60 year $^{-1}$, respectively, has earned the former the preference as an aquaculture candidate among the three cichlids. The growth rates of $O$. niloticus $(\mathrm{K}=0.58 \mathrm{yr}$ $\left.{ }^{1}\right)$ and T. zillii $\left(\mathrm{K}=0.60 \mathrm{yr}^{-1}\right)$ are almost similar; the former grows to a larger asymptotic length than the latter, giving O. niloticus the preference over T. zillii as a culturable species. Huet (1970) cited fast growth rate as one of the biological attributes for selecting a fish species for culture, hence the popularity of $O$. niloticus for culture world wide.

The length at first capture $\left(\mathrm{L}_{50 \%}\right)$ values obtained, ranging from 4.9-5.5 SL cm in this study for the minimum legal mesh size of $5 \mathrm{~cm}$ bar stretched (Ghana Fisheries Act 625, 2002), were considered small. For the purpose of conserving the fishery, cichlids larger than the present $L_{50 \%}$ should be captured. This strategy could, however, lead to recruitment over fishing (Pauly et al.,1989; Sparre \& Venema, 1992) because of decline in larger spawning species. Therefore, it may be reasonable to increase the $\mathrm{L}_{50 \%}$ by increasing the minimum legal mesh size of gillnet, taking into consideration the danger of spawning stock depletion.

The strategy could be applied by enforcing the estimated minimum precautionary mesh size of $10 \mathrm{~cm}$ for catching $S$. galilaeus, H. faciatus and B. nurse in the reservoir (Kwarfo-Apegyah, 2008), based on selection factor of the legal minimum mesh size of $5 \mathrm{~cm}$ (Ghana Fisheries Act 625, 2002). This calls for an upward review of the Ghana Fisheries Act 625 (2002) of the minimum mesh size of gillnets for Bontanga reservoir fisheries and, by extrapolation, all reservoir fisheries in Ghana from 5 to $10 \mathrm{~cm}$, for conservation and sustainable exploitation.

The $Y^{\prime} / R$ curve indicates that present level of exploitation $\left(E_{\text {presen }}\right)$ of the species lie to the left of $\mathrm{E}_{\max }$, indicating that the current exploitation rates of the species appear inadequate for maximal utilization of the stocks. However, the B'/R curve of $S$. galilaeus indicates that at $\mathrm{E}_{\text {present }},>50 \%$ of biomass-per recruit were fished, a situation that could lead to growth over fishing. Therefore, by enforcing the precautionary minimum mesh size of $10 \mathrm{~cm}, \mathrm{~L}_{50 \%}$ would increase and allow the survival to fishing of more reproductive adults to spawn to replenish the stocks.

The $F_{\text {MSY/R }}$ was higher than $F_{\text {present }}$ for all the species, suggesting that bigger yields could be expected by increasing $\mathrm{F}_{\text {present }}$. However, in view of the low natural mortality rate ranging form 0.71.41 , it is ecologically worthwhile to allow the fish to grow to larger size to contribute to the biomass which means that, for biologically optimum exploitation, F should be low (Sparre \& Venema, 1992). Therefore, it is prudent to restrict further entry into the fishery rather than to increase $\mathrm{F}_{\text {present }}$. Restriction of further entry into the fishery, adoption of closure measures and 
enforcement of precautionary minimum mesh size of $10 \mathrm{~cm}$ of gill nets will enhance recruitment, and ensure conserva-tion and sustainable exploitation of fish stocks of the reservoir.

\section{Acknowledgement}

The study was funded by the Water Research Institute (WRI) of the Council for Scientific and Industrial Research (CSIR) as part of the Institute's reservoir fisheries enhancement programme. The permission of the Director to publish this work is gratefully acknowledged.

\section{References}

Amarasinghe U. S., De Silva S. S. and Moreau J. (1989). Spatial changes in growth and mortalty and effects on the fishery of Oreochoromis mossambicus (Pisces, Cichlidae) in a man-made lake in Sri-lanka. Asian Fish. Sci. 3:57-68.

Amevenku F. Y. and QuarcoopomeT. (2006). Fish and fisheries of Bontanga and Libga reservoirs in northern Ghana, West Africa. West Afr. J. appl. Ecol. 10: 9-19.

Bagenal T. B. and Braum E. (1968). Eggs and early life history. In Methods for assessment of fish production in fresh waters. (W. E. Ricker, ed.), pp.157-181. IBP Handbook No. 3, Blackwell Scientific Publications, Oxford.

Baijot E. J., Moreau J. and Bouda S. (1997). Hydrobiological aspects of fisheries in small reservoirs on the Sahel region. Technical Centre for Agricultural and Rural Cooperation (ACP-EU). The Hague, Netherlands. 238 pp.

Beverton R. J. H. and Holt S. J. (1957). On the dynamics of exploited fish populations. Fish. invest. Minist. Agric. Fish. Food. G.B. (2 sea fish) 19: 533p. In Introduction to tropical fish stock assessment, Part 1-Manual. (P. Sparre and S. C. Venema, ed.)FAO Fish. Tech. Pap. 306/1 Rev. 1376 pp.

Beverton R. J. H. and Holt S. J. (1966). Manual of methods for fish stock assessment. Part 2. Tables of Yield functions. FAO. Fish. Tech. Pap. 38, Rev. 1. 67 pp.

Dankwah H. R., Abban E. K. and Teugels G. G. (1999). Fresh water fishes of Ghana: Identification, distribution, ecological and economic importance. Anales Sci. zool. 283:

Environmental Protection Agency (EPA) (2004). United Nations Convention to Combat Desertification (UNCCD). Country Profile from the EPA Ghana, Report. 16 pp.

Gayanilo Jr. F. C., Sparre P. and Pauly D. (1994). The FAO-ICLARM stock assessment tools (FiSAT). Users guide. FAO computerized information series, fisheries Final draft. FAO, Rome.

Ghana Fisheries, Act 625. (2002). of the Government of Ghana.

Gulland J. A (1969). Manual of methods for stock assessment, Part1. Fish population Analysis. Manual of Fish. Sci. Vol. 4 . FAO, Rome.

Huet M. (1970). Text book of fish culture, breeding and cultivation of fish. Fishing News Books, Surrey, England: 436 pp.

Iles T. D. (1970). Ecological aspects of growth in cichlid. Fishes. J. cons. Int. Explor. Mer. 33: 363-385.

Iles T. D. (1973). Dwarfing or stunting in Genus Tilapia (Cichlidae), a possibly unique recruitment mechanism. Rapp. P.V. Reun. Cons. Int. Explor. Mer. 164: 247-254.

King, M. (1995). Fisheries biology assessment and management. Fishing News Books, Blackwell Science Ltd, Osnymead, Oxford OXZ OEL, England.

Kwarfo-Apegyah K. (2008). Ecology and stock assessment of major fish species of Bontanga reservoir, northern Ghana for sustainable management (PhD Thesis.) University of Ghana, Legon, Accra, Ghana. 216 pp.

National Dam Safety Unit (NDSU) (2007). Engineering services for dam construction and rehabilitation. NDSU Report, 2007, revised edn.

Ofori-Danson P. K. (1999). Stock assessment of the five major commercial fish species in Yeji area (Stratum VII) of the Volta lake. (PhD Thesis.) Department of Oceanography and Fisheries, University of Ghana, Legon, Accra, Ghana. 189 pp.

Ofori-Danson P. K. (2005). An assessment of the purse seine Winchnet fishery in Lake Volta, Ghana. Lakes and Reservoirs. Research Management 10: 191-197.

Paugy D., Leveque C. and. Teugels G. G. (2003a). The fresh and brackish water fishes of West Africa Vol 1. 459 pp.

Paugy D., Leveque C. and. Teugels G. G. (2003b). The fresh and brackish water fishes of West Africa, Vol. 2. 815 pp.

Pauly D. (1979). Theory and management of tropical multispecies: a review with emphasis of the south east asian demersal fisheries. ICLARM Stud. Rev. 1: 35.

Pauly D. (1980). A selection of simple methods for the assessment of tropical fish stocks. FAO Fish.Circ. 729: 1-54.

Pauly D. (1984). Fish population dynamics in tropical waters, a manual for use with programmable calculators. ICLARM contribution. pp. 143-325.

Pauly D. (1995). Population dynamics of African fishes. Paper presented at the First Pan African Congress and Exhibition, 31 July-5 August 1995, Nairobi, Kenya. ICLARM Contribution No. 1162.

Pauly D., Silvestre G. and Smith J. R. (1989). On development fisheries and dynamite: a review of tropical fisheries management. Nat. Resour. Model. 3(3): 307-329.

Ricker W. E. (1975). Computation and interpretation of statistics of fish population.Bull. Fish. Res. Board. Can. 191: 291-382.

Sparre P. and Venema S. C. (1992). Introduction to tropical fish stock assessment, Part 1. Manual. FAO. Fish. Tech. Pap. 306 /1 Rev. 1 FAO, Rome. 376 pp.

West African Journal of Applied Ecology, vol. 14, 2008 
West African Journal of Applied Ecology, vol. 14, 2008 
ERRATA

\begin{tabular}{|c|c|c|c|c|c|c|c|}
\hline \multicolumn{2}{|c|}{ LGG } & \multicolumn{2}{|c|}{ LG2 } & \multicolumn{2}{|c|}{ L63 } & \multicolumn{2}{|c|}{ LG4 } \\
\hline 0.0 & $\mathrm{AGC/CTC1}$ & 0.0 & АСА/СTT2 & 0.0 & АСА/СТT14 & 0.0 & АGС /САTЗ \\
\hline 0.0 & АСА/CTTI? & 29.9 & АСС/СТT6 & 24.1 & АСА/CTT4 & 29.6 & $\mathrm{AMC} / \mathrm{CAG}$ ? \\
\hline 28.8 & $\mathrm{AMC} / \mathrm{CaC5}$ & 42.4 & АСС/CTT8 & 50.5 & AM̈LCTTL2 & 47.6 & АСA/CTT16 \\
\hline 28.8 & $\triangle \mathrm{AGC/CTT5}$ & 66.0 & $\mathrm{AMC} / \mathrm{CAGS}$ & 63.1 & $\mathrm{M} A \mathrm{G} / \mathrm{CTG1}$ & 47.6 & AGC/CTC3 \\
\hline 76.6 & $\mathrm{AMC} / \mathrm{CAGI}$ & 78.9 & АСА/Сназ & 74.4 & AMG/CAG6 & & \\
\hline $102.1 /$ & AGC/CTT1 & 95.1 & АСС/CTT? & 113.5 & $\mathrm{AAMC} / \mathrm{CAGG}$ & & \\
\hline $102.1 /$ & АGC/CTA1 & 117.0 & Аа́с/Cас6 & 134.9 & AGC/CTAL & & \\
\hline 102.1 & $\mathrm{AM} \dot{\mathrm{A}} \mathrm{G} / \mathrm{CA} 65$ & 117.0 & 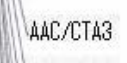 & 134.9 & $\mathrm{AMA} \mathrm{G} / \mathrm{CTG} 3$ & & \\
\hline 124.6 & АСА/СТT6 & 117.0 & 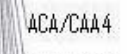 & 144.4 & ACA/CTG2 & & \\
\hline 124.6 & $\mathrm{H} \mathrm{AC} / \mathrm{CTC3}$ & 130.0 & АС̈/СTT10 & 173.0 & $\mathrm{AGC} / \mathrm{CHT} 4$ & & \\
\hline 149.2 & $\mathrm{ACC} / \mathrm{CTC1}$ & 139.1 & АБС/СТА? & 197.6 & МCA/CAMAOC & & \\
\hline 149.2 & MAL/CTA4 & 139.1 & ALAЛТTAS & $213.1 /$ & АGC/CTA5 & & \\
\hline 177.1 & АGC/CTÄ & 139.1 & AGC/CAT2 & 233.6 & асалсанда & & \\
\hline & & 152.7 & $\mathrm{AMC} / \mathrm{CH} 63$ & 233.7 & ÁGC/CTC2 & & \\
\hline & & 161.2 & аСС/CTT5 & & & & \\
\hline & & 161.3 & АСА/СТТ8 & & & & \\
\hline & & 185.5 & ACA/CAMAll & & & & \\
\hline & & 201.5 & АСА/Сднд8 & & & & \\
\hline & & 212.9 & AGC/CATI & & & & \\
\hline & & 212.9 & АСС/CTC3 & & & & \\
\hline & & 235.1 & AMG/CACG & & & & \\
\hline & & 235.1 & 能/CAC2 & & & & \\
\hline & & 235.1 & АСА/СТT13 & & & & \\
\hline & & 235.1 & АGC/LAT7 & & & & \\
\hline & & 235.1 & $\mathrm{ACH} / \mathrm{CAM3}$ & & & & \\
\hline & & 235.1 & 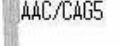 & & & & \\
\hline & & 264.8 & АСА/СТT19 & & & & \\
\hline & & 285.2 & 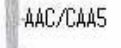 & & & & \\
\hline & & 307.6 & $\mathrm{AMC} / \mathrm{CAH} 2$ & & & & \\
\hline & & 324.2 & АСС/СТТЗ & & & & \\
\hline & & 324.2 & АGС/CTA9 & & & & \\
\hline & & 354.6 & 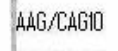 & & & & \\
\hline & & 382.8 & $\mathrm{MAC} / \mathrm{CAM} 6$ & & & & \\
\hline & & 406.1 & $\mathrm{AMG} / \mathrm{CAG} 2$ & & & & \\
\hline & & 416.6 & AMGG/CÄG3 & & & & \\
\hline
\end{tabular}




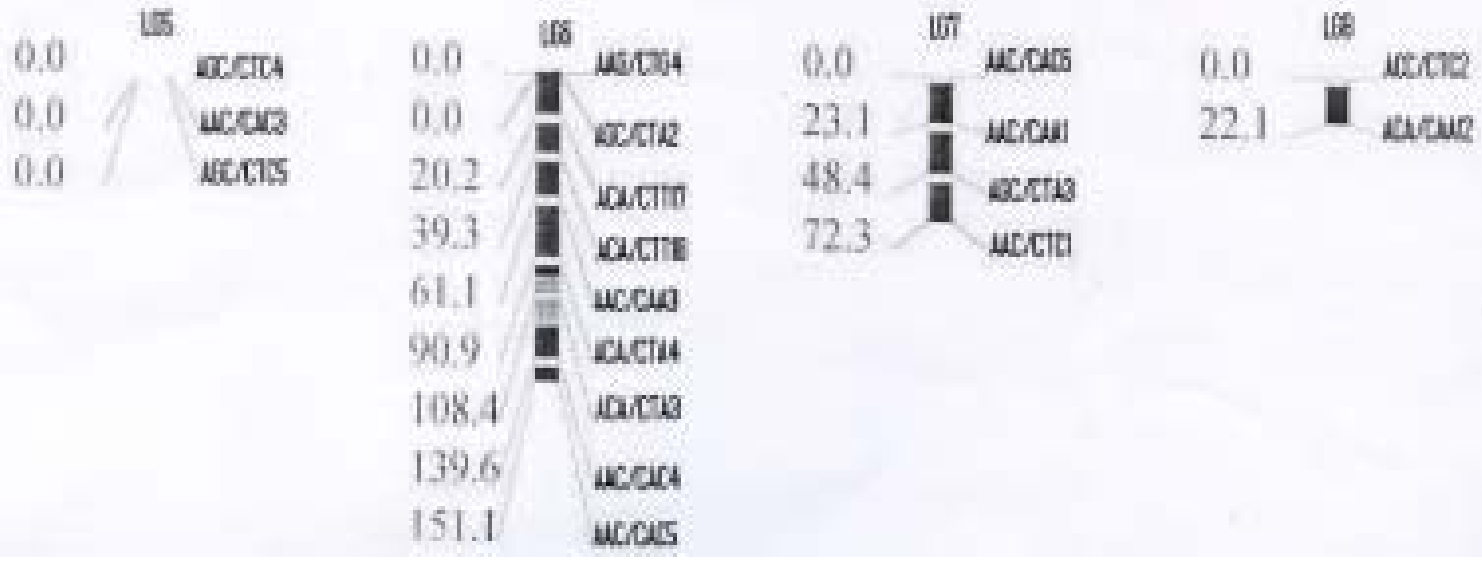

Fig.1 cont'd. Linkage map of Vigna unguiculata. Linkage group numbers are indicated on the top. Cumulative Kosami map distances are indicated at the left side of each marker. 


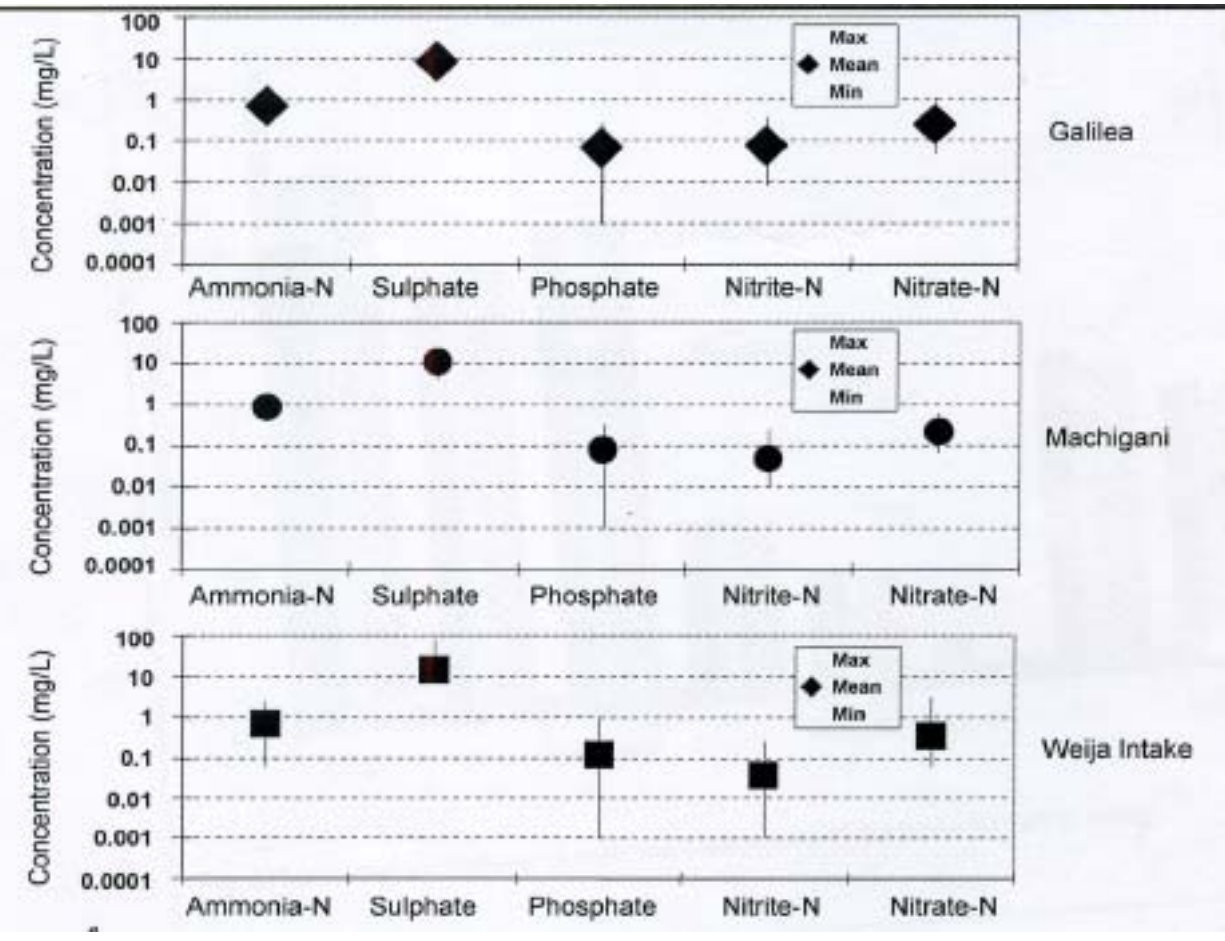

Fig. 4. Nutrient levels among the three sampling sites

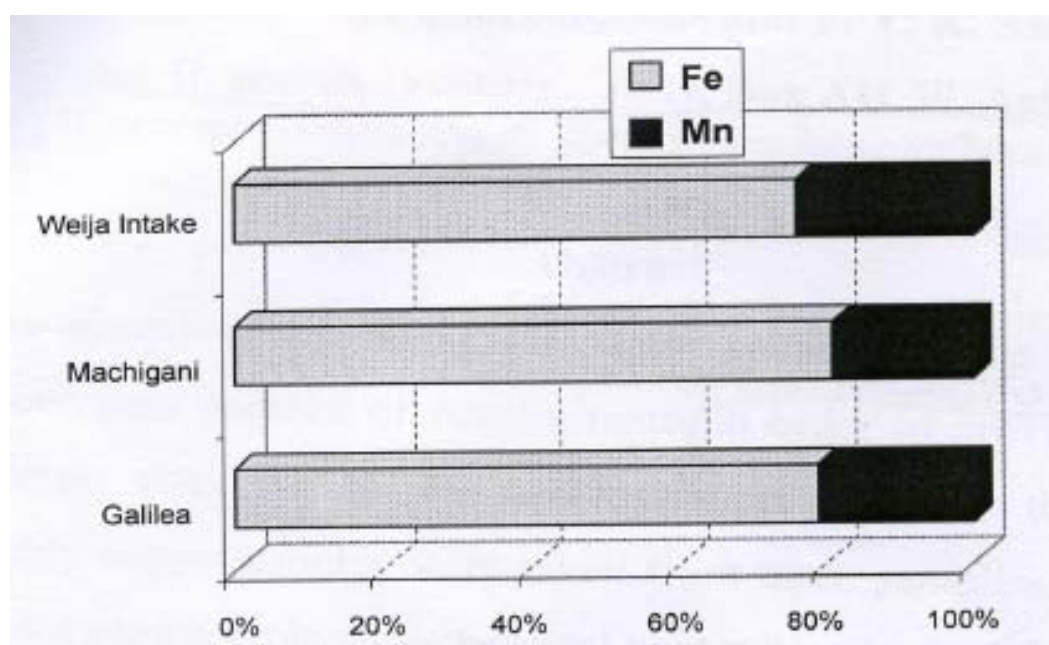

Fig. 5. Percentage levels of iron (Fe) and manganese (Mn) from the three sampling sites. 


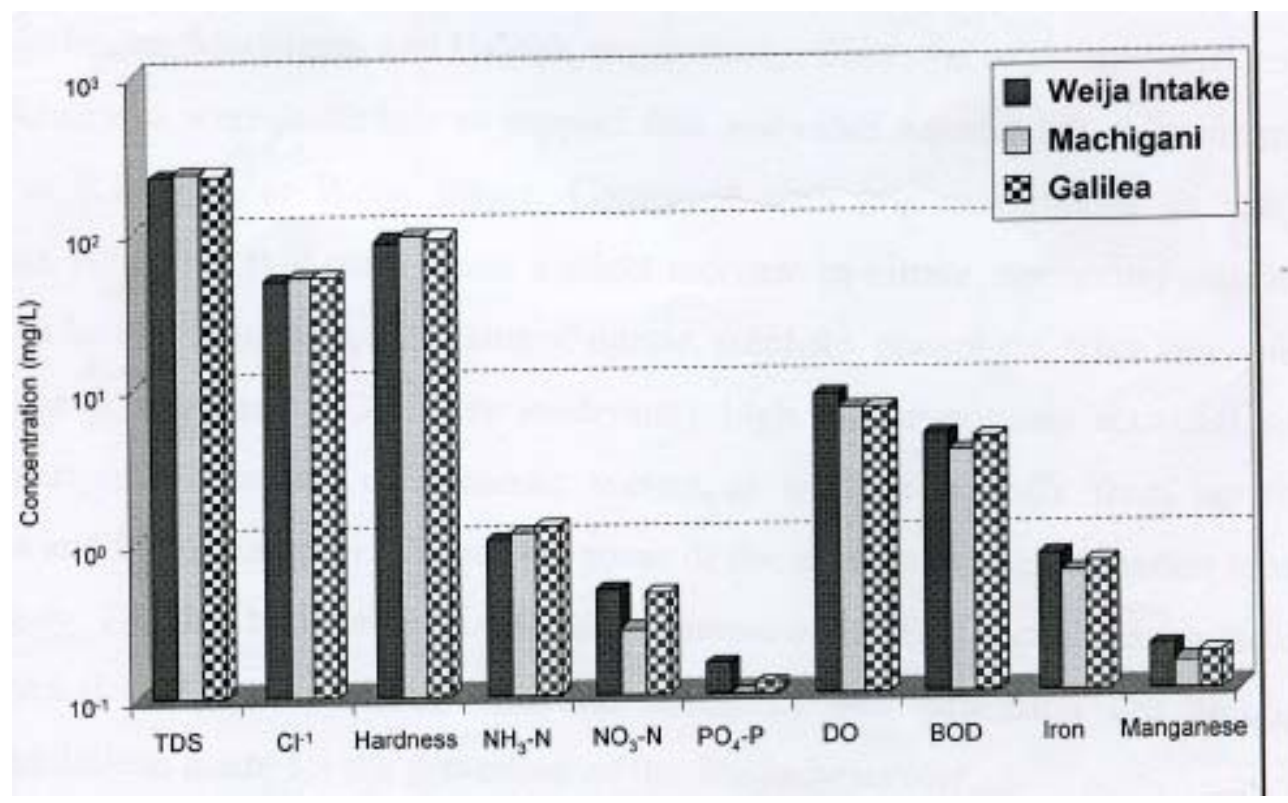

Fig. 6. Mean concentrations of selected parameters of the three sampling sites

TABLE 1

Concentrations of measured parameters in water samples from the study area. All results are in mg-l except conductivity $(\mu \mathrm{S} / \mathrm{cm})$, turbidity $(\mathrm{FTU})$, colour $(\mathrm{Hz})$ and $\mathrm{pH}(\mathrm{pH}$ units)

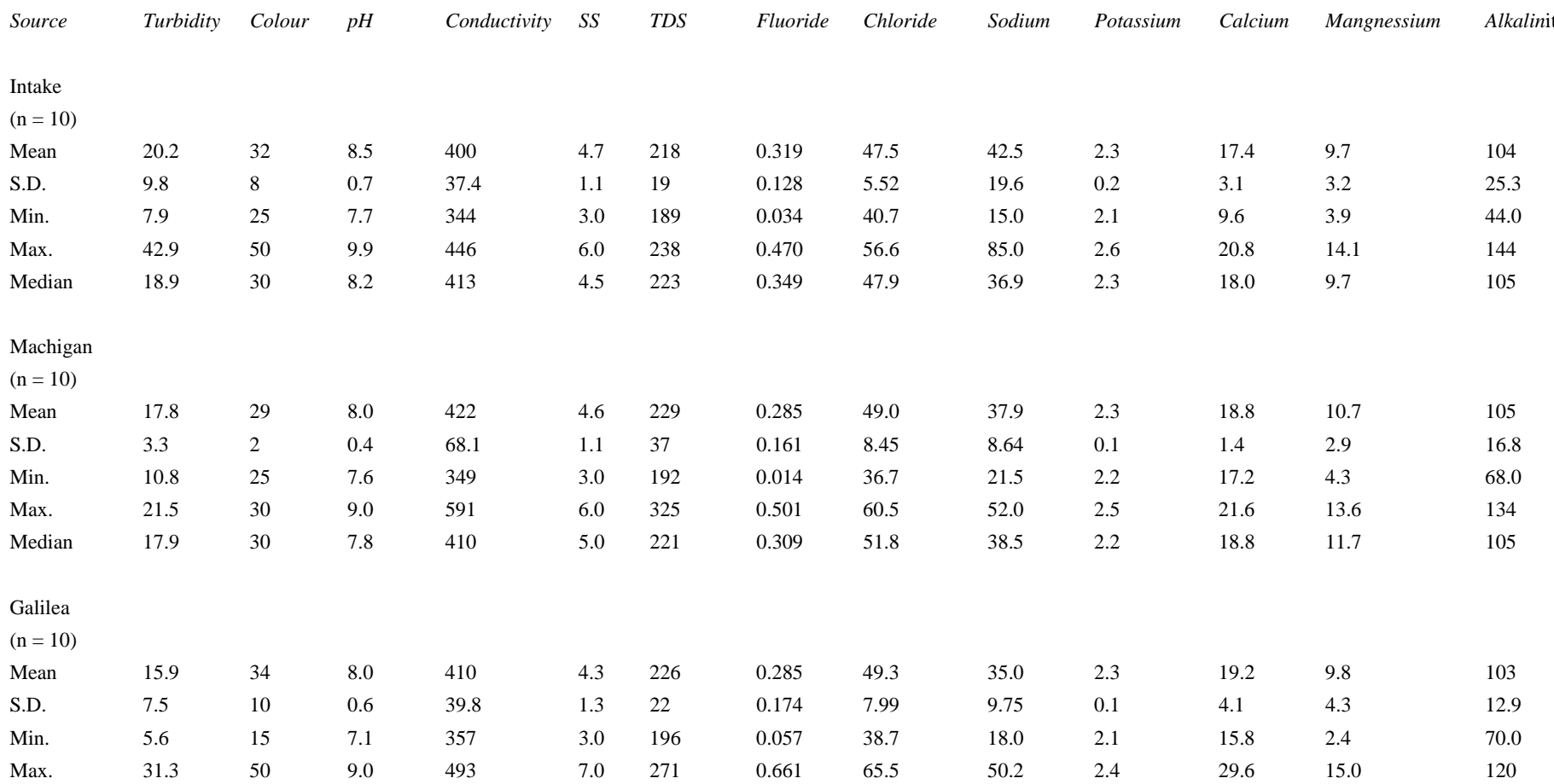

WHO

Drinking

water

$\begin{array}{lllllllllll}\text { guidelines } & 5 & 15 & 6.5-8.5 & 1000 & 1.5 & 250 & 200 & 30 & 200 & 150\end{array}$ 
TABLE 1 continued

Concentrations of measured parameters in water samples from the study area. All results are in mgl except conductivity $\mu \mathrm{S} / \mathrm{cm}$, turbidity (FTU), colour (Hz) and $\mathrm{pH}$ ( $\mathrm{pH}$ units)

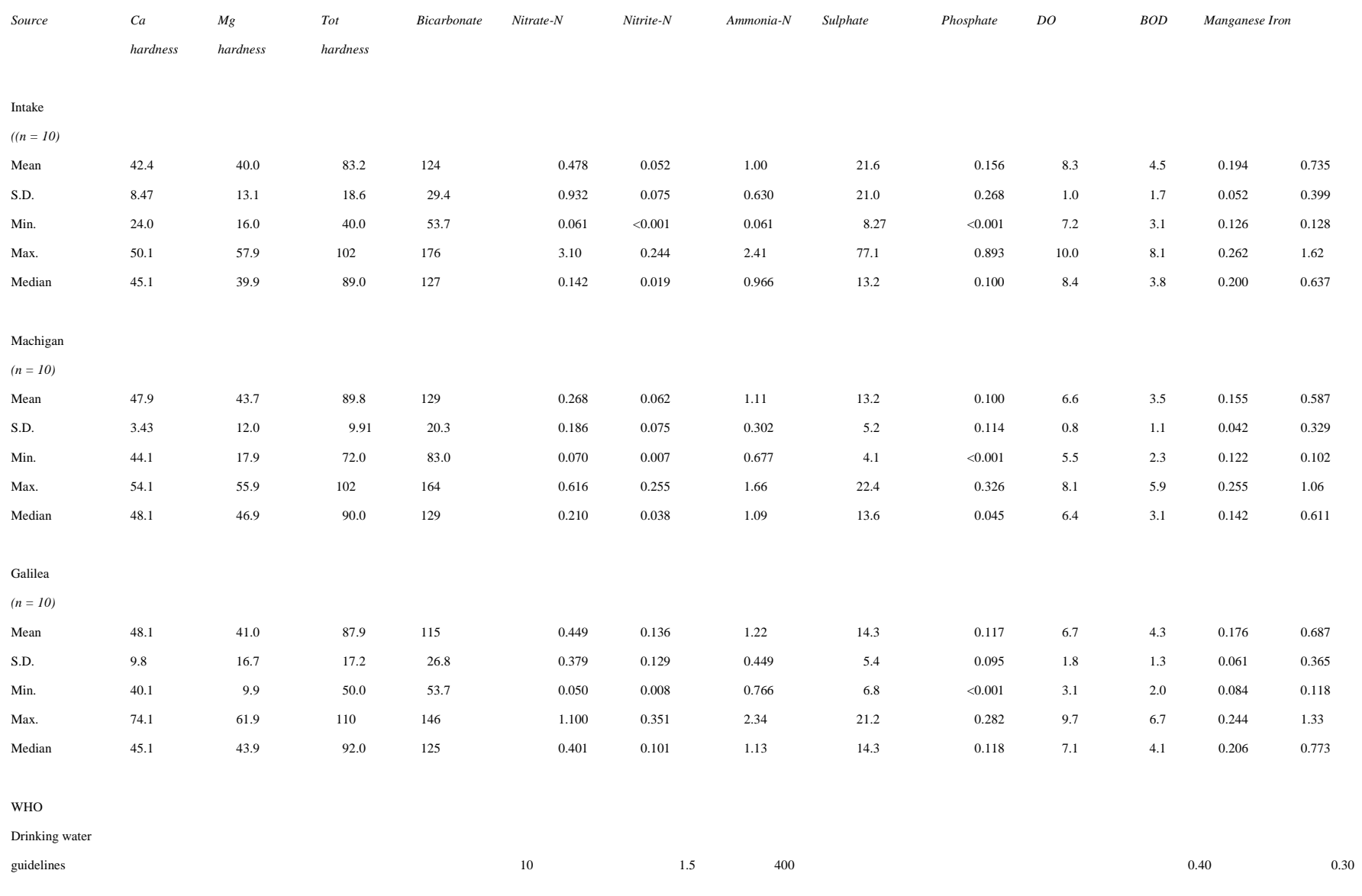

TABLE 3

Chronology of some physico-chemical studies of the Weija Reservoir. All results are in $\mathrm{mg} / \mathrm{l}$ except conductivity $(\mathrm{mS} / \mathrm{cm})$, turbidity (NTU), colour $(\mathrm{Hz})$ and $\mathrm{pH}$ ( $\mathrm{pH}$ units)

$\begin{array}{lllll}\text { Parameter } & 2005^{*} & 1997^{*} & 1993-1997^{*} & 1978^{*} \\ \text { Turbidity } & 5.6-42.9(18) & \text { NA } & \text { NA } & \text { NA } \\ \text { Colour } & 15-50(31.7) & \text { NA } & \text { NA } & \text { NA } \\ \text { pH } & 7.1-9.9(8.2) & 7.4-8.1 & 7.3-7.7 & 6.83-7.25 \\ \text { Conductivity } & 344-591(411) & 224-282 & \text { NA } & 360-1550 \\ \text { Suspended solids } & 3.0-7.0(5) & 91-132 & \text { NA } & \text { NA } \\ \text { Total dis. solids } & 189-325(224) & 144-201 & \text { NA } & \text { NA } \\ \text { Fluoride } & 0.014-0.661(0.296) & \text { NA } & \text { NA } & \text { NA } \\ \text { Chloride } & 36.7-65.5(48.6) & 37.4-38.4 & \text { NA } & 5.0-48.0 \\ \text { Sodium } & 15-85(38.4) & 24.1-25.0 & \text { NA } & \text { NA } \\ \text { Potassium } & 2.1-2.6(2.3) & 2.07-4.46 & \text { NA } & \text { NA } \\ \text { Calcium } & 9.6-29.6(18.4) & 15.9-16.4 & \text { NA } & 16.3-30.3 \\ \text { Magnessium } & 2.4-15.0(10.1) & 10.2-13.7 & \text { NA } & 10.6-25.8 \\ \text { Alkalinity } & 44-144(104) & 83.6-96.9 & 108-131 & 73-153 \\ \text { Ca hardness } & 24.0-74.1(46.1) & \text { NA } & \text { NA } & \text { NA } \\ \text { Mg hardness } & 9.9-61.9(41.6) & \text { NA } & \text { NA } & \text { NA } \\ \text { Total hardness } & 40-110(87) & 83.1-96.8 & \text { NA } & 59.8-136.9 \\ \text { Bicarbonate } & 53.7-176(123) & 102-118 & \text { NA } & \text { NA }\end{array}$

West African Journal of Applied Ecology, vol. 14, 2008 


$\begin{array}{lllll}\text { Nitrite-nitrogen } & 0.05-3.1(0.398) & 0.07-0.78 & 0.20-2.42 & 0.012-0.051 \\ \text { Nitrite-nitrogen } & 0.001-0351(0.083) & <0.01 & 0.004-2.00 & 0.005-0.076 \\ \text { Ammonia-nitrogen } & 0.061-2.41(1.11) & \text { NA } & 0.001-0.64 & <0.01-1.5 \\ \text { Sulphate } & 4.14-77.1(16.4) & 5.57-13.3 & 4.00-15.2 & 0.725-29.5 \\ \text { Phosphate } & 0.001-0.893(0.124) & 0.47-067 & \text { NA } & 0.25-1.45 \\ \text { DO } & 3.1-10.0(7.2) & 5.9-7.32 & 7.9-10.4 & 0.05-3.8 \\ \text { BOD } & 2.0-8.1(4.1) & \text { NA } & 5.48-8.16 & 0.05-3.8 \\ \text { Manganese } & 0.084-0.262(0.175) & \text { NA } & \text { NA } & \text { NA } \\ \text { Iron } & 0.102-1.62(0.669) & \text { NA } & \text { NA } & \text { NA }\end{array}$

NA: No available date. Values in parentheses are mean concentrations.

*Year 2005 (this study) = Asante et al.

*Year 1997 study = Bosque-Hamilton et al. (2004)

*Year 1993-1997 study = Ansa-Asare \& Asante (1998)

*Year 1978 study = Biney \& Kpekata (1978)

*Year 1997 study = Bosque-Hamilton

The errors are regretted. 